Utah State University

DigitalCommons@USU

\title{
First-Year Postfire and Postharvest Soil Temperatures in Aspen and Conifer Stands
}

Michael C. Amacher

Amber D. Johnson

Debra E. Kutterer

Dale L. Bartos

Follow this and additional works at: https://digitalcommons.usu.edu/aspen_bib

Part of the Forest Sciences Commons

\section{Recommended Citation}

Amacher, MC. et al. 2001. First-year postfire and postharvest soil temperatures in aspen and conifer stands. USDA Forest Service, Research Paper RMRS-RP-27. Rocky Mountain Research Station, Ogden UT

This Report is brought to you for free and open access by the Aspen Research at DigitalCommons@USU. It has been accepted for inclusion in Aspen Bibliography by an authorized administrator of DigitalCommons@USU. For more information, please contact

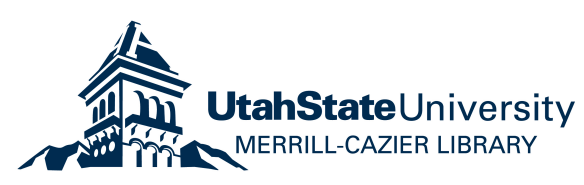


USDA

United States

Department

of Agriculture

Forest Service

Rocky Mountain

Research Station

Researach Paper

RMRS-RP-27-WWW

February 2001

近出

\section{First-Year Postfire and Postharvest Soil Temperatures in Aspen and Conifer Stands}

Michael C. Amacher

Amber D. Johnson

Debra E. Kutterer

Dale L. Bartos

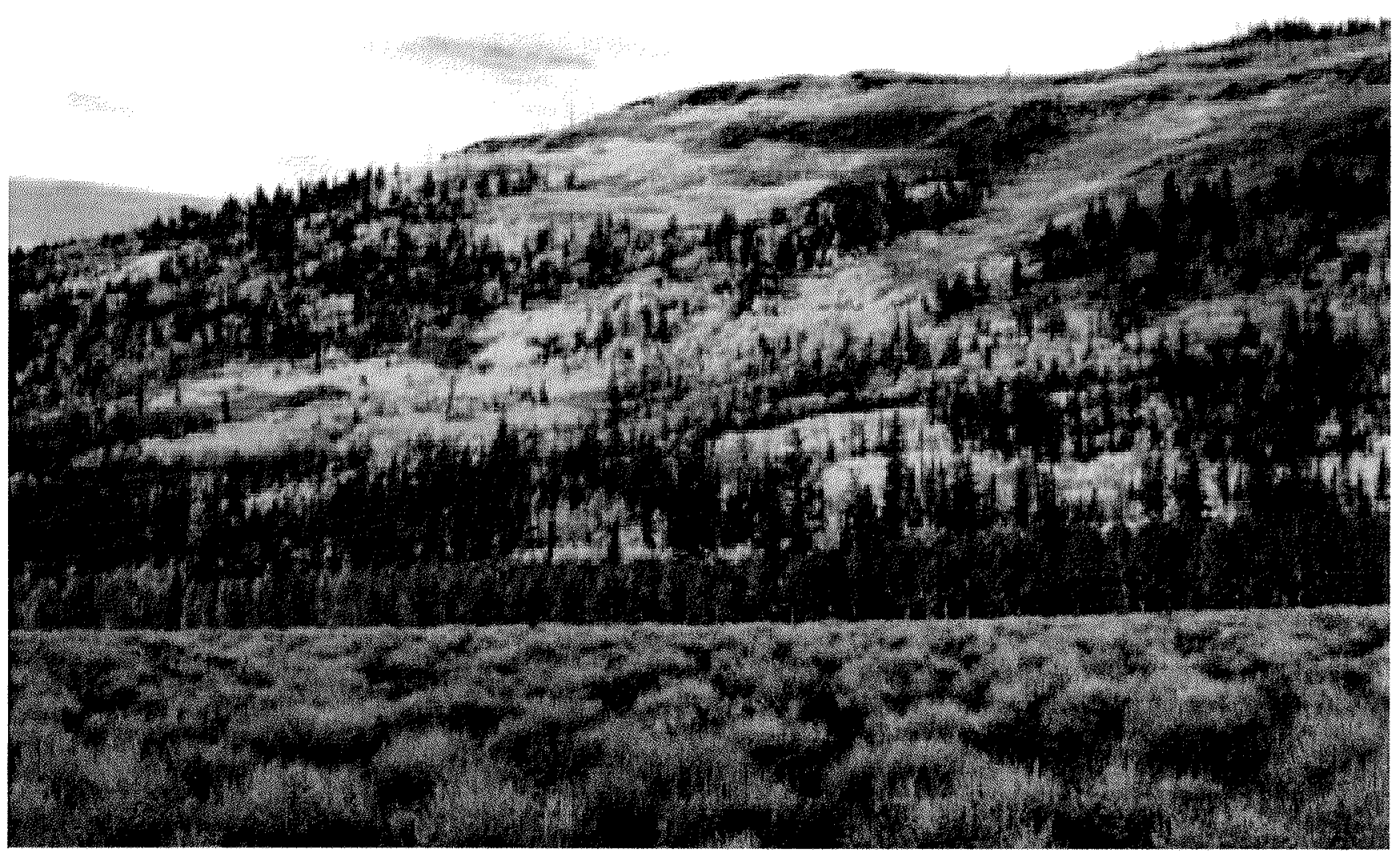




\section{Abstract}

Amacher, Michael C.; Johnson, Amber D.; Kutterer, Debra E.; Bartos, Dale L. 2001. First-year postfire and postharvest soil temperatures in aspen and conifer stands. Res. Pap. RMRS-RP-27-WWW. Ogden, UT: U.S. Department of Agriculture, Forest Service, Rocky Mountain Research Station. 24 p.

Aspen (Populus tremuloides Michx.) stands are in decline throughout the Interior Western United States because of fire suppression, overbrowsing by domestic livestock and native ungulates, and forest succession. We measured summertime soil temperatures in stable aspen, decadent aspen, and mixed aspen/conifer stands; a mixed aspen/conifer clearcut; a mixed aspen/conifer forest that was burned in a lightning-caused fire; and a decadent aspen stand and mixed aspen/conifer stand that received prescribed burns. Soil temperature fluctuations and mean soil temperatures were greater in cut and burned areas than in untreated stands. In untreated stands, mean soil temperature increased in the order: mixed aspen/conifer < stable aspen < decadent aspen. Soils under the closed canopy of mixed aspen/conifer stands tended to remain cool in the summer favoring organic matter accumulation. The relatively open canopy of decadent aspen stands allowed for increased light penetration and soil heating favoring organic matter breakdown. Cutting and burning greatly increased summertime shallow soil temperature, also favoring increased organic matter turnover and aspen suckering. Postdisturbance regrowth of grasses and forbs and aspen suckering shaded soils. Eventually, soil temperature in treated or disturbed areas should approach that of stable aspen stands.

Keywords: forest succession, grazing, Populus tremuloides Michx., erosion, forest health

\section{The Authors}

Michael C. Amacher is a Research Soil Scientist with the Reclamation of Disturbed Lands Research Work Unit at the Forestry Sciences Laboratory in Logan, UT. He holds B.S. and M.S. degrees in chemistry and a Ph.D. degree in soil chemistry, all from The Pennsylvania State University. He joined the Rocky Mountain Research Station in 1989. He studies the effects of natural and human-caused disturbances on soil properties and develops methods for restoring disturbed ecosystems.

Amber $\mathrm{D}$. Johnson is a former Student Intern with the Reclamation of Disturbed Lands Research Work Unit at the Forestry Sciences Laboratory in Logan, UT. She holds a B.S. degree in Environmental Studies from Utah State University, served as a Peace Corps volunteer in Bolivia, and is now a graduate student at the University of lowa.

Debra E. Kutterer is a former Student Intern with the Reclamation of Disturbed Lands Research Work Unit at the Forestry Sciences Laboratory in Logan, UT. She holds a B.S. degree in Bioveterinary Science at Utah State University and is a student in the Professional Veterinary Medicine Program in the College of Veterinary Medicine and Biomedical Sciences at Colorado State University.

Dale L. Bartos is a Research Ecologist with the Reclamation of Disturbed Lands Research Work Unit at the Forestry Sciences Laboratory in Logan, UT. He holds B.S. and M.S. degrees from Fort Hays Kansas State University and a Ph.D. degree in Range Science from Colorado State University. He joined the Rocky Mountain Research Station in 1972. He studies aspen ecology and methods of restoring aspen ecosystems in the Interior Western United States.

Rocky Mountain Research Station 324 25th Street Ogden, UT 84401 


\section{Acknowledgments}

This work was supported by USDA-CSREES Rangelands Special Grant No. 9638300-3022. We thank Scott Walker of the Utah Division of Wildlife Resources for funding construction of the exclosures. We thank Bob Campbell and other Fishlake National Forest personnel for their able assistance throughout the project. We also thank Dandy Pollock, Doug Sorenson, and crew for building the exclosures. We thank Rudy King and Dave Turner for the time series analysis of the temperature data. We also thank Walt Mueggler, Charles Kay, and Wayne Shepperd for their helpful comments on an earlier version of this paper.

\section{Contents}

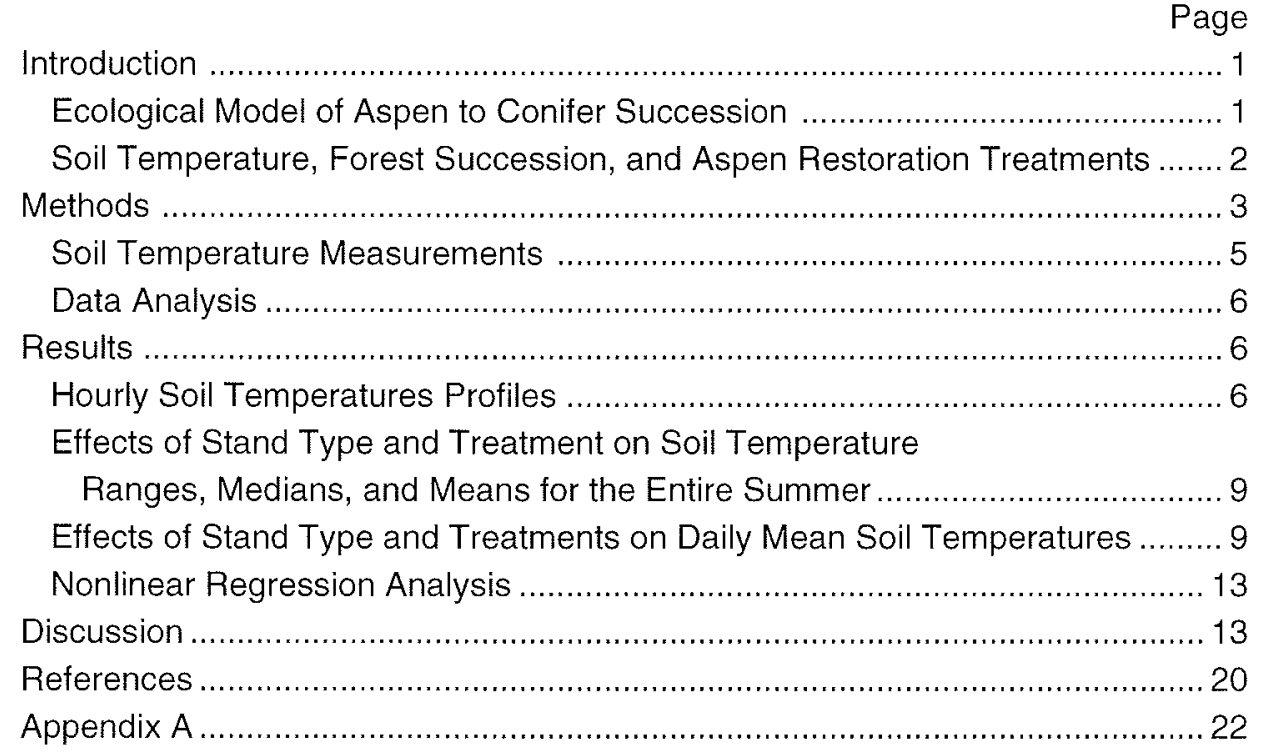

The use of trade or firm names in this publication is for reader information and does not imply endorsement by the U.S. Department of Agriculture of any product or service. 


\title{
First-Year Postfire and Postharvest Soil Temperatures in Aspen and Conifer Stands
}

\author{
Michael C. Amacher \\ Amber D. Johnson \\ Debra E. Kutterer \\ Dale L. Bartos
}

\section{Introduction}

Aspen (Populus tremuloides Michx.) provides many ecological benefits to resource users including protection of watersheds from erosion, some protection against rapid wildfire advance, increased biological diversity in the species rich grass-forb understory, wood fiber, wildlife habitat, forage for domestic livestock and native ungulates, recreational sites, esthetic considerations (e.g., fall leaf colors), and more water yield than conifers (Bartos and Campbell 1998a). Some authors have suggested that aspen stands are in decline throughout the Interior Western United States (Bartos and Campbell 1998a). Although the extent of decline has been the subject of much debate, National Forest inventory and analysis data indicate that about $60 \%$ have disappeared since the mid-19th century (Bartos and Campbell 1998b). Decline of aspen stands is attributed to forest succession (e.g., invasion of conifers) (Harniss 1981), fire suppression (Jones and Debyle 1985b), and overbrowsing by domestic livestock and native ungulates (Bartos and Mueggler 1981; Bartos and others 1994; Kay 1985, 1990, 1995; Kay and others 1994). Aspen decline from overbrowsing, fire suppression, and conifer invasion was noted as early as 1925 (Baker 1925).

Bartos and Campbell (1998a) identified five factors associated with declining aspen stands. These are: (1) more than $25 \%$ of the trees in the stand are conifers, (2) aspen canopy cover is less than $40 \%$, (3) the dominant aspen trees in the stand are more than 100 years old, (4) aspen regeneration is less than 500 stems/acre where the stems are 5 to $15 \mathrm{ft}$ in height, and (5) sagebrush cover is greater than $10 \%$. The presence of any of these factors identifies a declining aspen stand.

Western aspen, which reproduce primarily by suckering from lateral roots, often need disturbances to stimulate the suckering response (Schier 1981). In the past, these disturbances included lightning-caused fires that killed mature aspen and insects and diseases that weakened old decadent stands before toppling by wind. Suppression of human-caused and

lightning-caused fires throughout the 20th century has greatly reduced one of the main forces of aspen regeneration. Even when a disturbance such as fire or wind does stimulate aspen regeneration, overbrowsing of new aspen suckers by domestic livestock and native ungulates quickly suppresses regeneration (Kay 1993, 1997; White and others 1998). Overbrowsing and conifer and sagebrush invasion of declining aspen stands has led to the precarious state of aspen in the Interior Western United States. This forest health issue has been emerging over the past several decades and needs to be addressed soon to restore aspen as an integral part of forest diversity in the Western United States.

\section{Ecological Model of Aspen to Conifer Succession}

Cryer and Murray (1992) proposed an ecological model of aspen to conifer succession that indicates that aspen regeneration may be inhibited on landscapes that are dominated by conifers. This occurs because conifers may alter soil properties to such an extent that aspen regeneration is suppressed.

Soils in the Western United States that developed under stable aspen are Mollisols. The O (organic) horizon is absent or very thin and the A (surface mineral) horizon is thick and mollic (dark and enriched with organic matter). The rapid breakdown of aspen leaves added to the soil each year during leaffall (Bartos and DeByle 1981) contributes to formation of the mollic horizon (Cryer and Murray 1992; Jones and DeByle 1985a).

Aspen stands usually have a significant grass-forb understory. The rapid breakdown of organic matter from this understory also contributes to the formation and maintenance of the mollic horizon. Declining aspen stands without significant conifer invasion may also have a significant sagebrush understory. Breakdown of grasses, forbs, and shrub leaves in decadent aspen stands may compensate for decreasing aspen leaf fall and maintain the mollic horizon to some 
extent. However, continued trampling by ungulates and overgrazing of grasses and forbs often leads to increased soil compaction, decreased infiltration, and increased runoff and erosion.

Soils developed under conifers in the climatic conditions of the Interior Western United States are primarily Alfisols. These soils often have significant $O$ horizons of conifer needles in various stages of decomposition, have a relatively thin A horizon, may have an albic(leached) E horizon, and have a prominent argillic $B$ horizon where layer silicate clays accumulate(Cryer and Murray 1992; Jones and DeByle 1985a; Rust 1983).

In declining aspen stands, decreasing leaf fall can lead to a decrease in organic matter accumulation and eventually a decrease in mollic horizon thickness (Cryer and Murray 1992). This may result in increased water infiltration through the soil profile and formation of an albic horizon. Conifer invasion can accelerate this process. In the theory of ecological succession proposed by Cryer and Murray (1992), as conifers invade declining aspen stands, the mollic horizon thins, while albic and argillic horizons form resulting in soil $\mathrm{pH}$, organic matter, exchangeable bases, cation-exchange capacity (CEC), nutrient levels, and soil temperature decreasing. The lower $\mathrm{pH}$ and nutrient levels are postulated to suppress aspen regeneration.

Soils under mixed aspen/conifer stands are usually transition soils with properties intermediate between Mollisols and Alfisols. In such cases, soil properties are most influenced by vegetation that has occupied the site the longest (Jones and DeByle 1985a). Although the processes and soil property changes described in the Cryer and Murray (1992) ecological succession model occur at different time scales, some soil profile alteration can occur after only one generation of conifers (Jones and DeByle 1985a).

In a preliminary study of soil properties under aspen and mixed aspen/conifer stands in the Burnt Flat Analysis Area of the Fishlake National Forest, UT, Bartos and Amacher (1998) found that conifer invasion had not appreciably altered the nutrient status of these soils, although a slight reduction in soil $\mathrm{pH}$ occurred under mixed aspen/conifer stands compared to pure aspen stands. These findings cast some doubt on whether conifer invasion of declining aspen stands does significantly alter soil properties. The findings also indicate that these soils should support aspen regeneration following treatment.

However, uncertainty remains about whether fire is needed to return nutrients to the soil to support aspen regrowth in areas where conifers have invaded. Where nutrient return is unnecessary, cutting alone may be sufficient to stimulate regeneration. In either case, protecting regenerating aspen from overbrowsing is important.
The ecological condition of aspen stands in the Interior Western United States and the need to initiate regeneration of declining aspen stands provided an ideal opportunity to quantify the effects of aspen to conifer succession and aspen restoration treatments (cutting and burning) on soil properties (primarily nitrogen $[\mathrm{N}]$ and phosphorus $[\mathrm{P}]$ mineralization).

\section{Soil Temperature, Forest Succession, and Aspen Restoration Treatments}

Soil temperature is an important soil property potentially affected by forest succession processes and aspen restoration treatments. Increasing soil temperature accelerates seed germination, root growth, suckering, soil drying, mineral weathering, and soil microbial activity. Microbial activity, in turn, controls element mineralization and immobilization (e.g., $\mathrm{N}$ and $\mathrm{P}$ ). Mineralization is the release of organic forms of $\mathrm{N}$ to mineral forms $\left(\mathrm{NH}_{4}\right.$ and $\left.\mathrm{NO}_{3}\right)$ via microbially mediated reactions. Immobilization is the transformation of mineral forms of $\mathrm{N}$ into organic $\mathrm{N}$, again via microbially mediated reactions (Stevenson 1986).

Soil temperature has a major effect on aspen suckering response (Maini and Horton 1966a,b; Steneker 1974; Williams 1972; Zasada and Schier 1973). Warmer soil temperature stimulates cytokinin production by root meristems (Williams 1972) and may also lower auxin concentrations in roots by accelerating its degradation (Schier and others 1985). The effect is a higher ratio of cytokinins to auxin, which stimulates aspen suckering (Peterson 1975; Winton 1968; Wolter 1968).

We hypothesize that soil temperature in aspen stands is affected by succession as shown in figure 1. In stable, regenerating aspen stands, the leaf canopy, even at shallow depths, keeps the soil relatively cool in the summer. In declining aspen stands without conifers, summertime shallow soil temperatures are greater than in stable aspen stands because of greater solar radiation penetrating the relatively sparseleaf canopy. However, increased invasion of grasses, forbs, and shrubs into declining aspen stands may help mitigate the increase in soil temperature. Overgrazing by domestic livestock or native ungulates would eliminate any shading benefit from grasses, forbs, and shrubs. In declining aspen stands with invading conifers, soils are kept relatively cool by the shading effect of conifers. Summertime shallow soil temperatures are lowest in climax spruce-fir forests where almost all the aspen have been replaced. The Cryer and Murray (1992) model of ecological succession predicts that soil temperature decreases as Mollisols are changed to Alfisols by conifer invasion of aspen. As soil temperature decreases, microbial activity decreases, thus favoring accumulation of soil organic matter. 


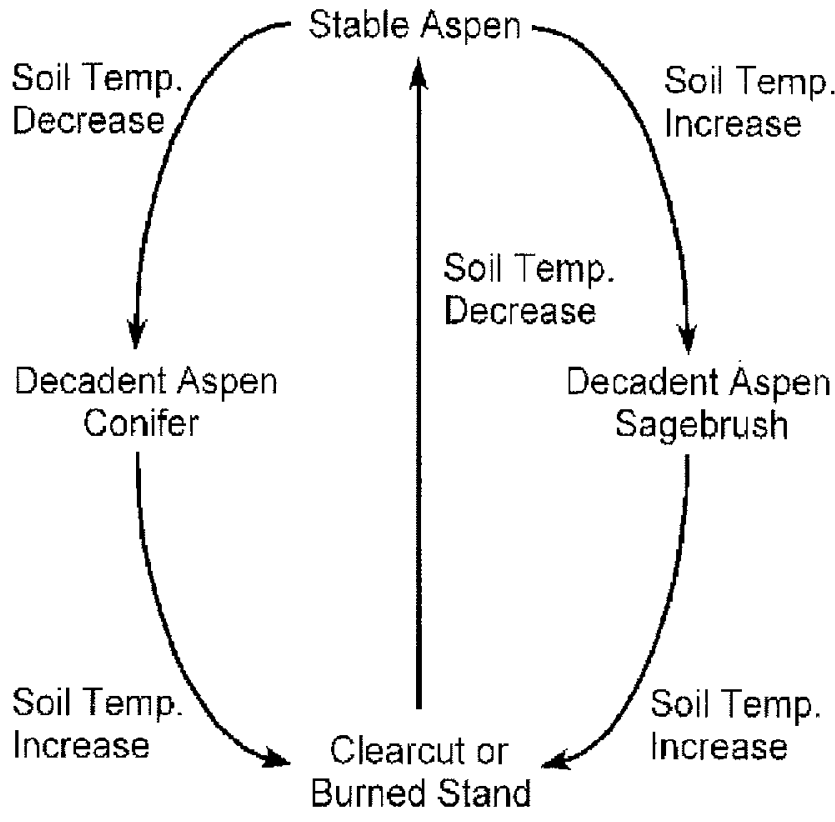

Figure 1-Descriptive model of summertime soil temperature changes resulting from forest succession processes and aspen stand treatments.

Clearcutting and burning treatments increase soil temperature (e.g., Hungerford and Babbitt 1987). Soil temperature increases after clearcutting because the leaf canopy has been removed. Slash left on the ground acts as a mulch and helps mitigate the increased heating of the soil surface (Hallin 1968). Burning also removes the tree canopy but, depending on the intensity of the burn, the dark-colored ash on the ground following a fire will promote increased soil heating because more solar radiation is absorbed. Summertime soil temperatures at several depths in burned aspen were higher than corresponding soil temperatures under unburned aspen during the first year after a prescribed burn (Hungerford 1988).

Soil temperature differences between unburned and burned aspen decreased the second and third summer following a prescribed burn (Hungerford 1988). As aspen regeneration and regrowth of grasses, forbs, and shrubs proceed, summertime soil temperatures decrease because of shade from new plant canopies (Hungerford and Babbitt 1987) and because of plant litter that acts as a mulch.

The increase in soil temperature following cutting or burning will accelerate microbial activity, organic matter breakdown, and $\mathrm{N}$ mineralization (Stevenson 1986). The accelerated breakdown of residual ash from a fire or slash from a clearcut is an important source of nutrients for aspen suckers until leaf fall and decay can again supply the nutritional needs of aspen.

This paper presents summertime shallow soil temperature measurements in the first year following clearcutting and burning of declining aspen stands. These data are compared to summertime shallow soil temperatures under stable aspen and untreated declining aspen with and without conifers. The effects of succession and aspen restoration treatments on soil $\mathrm{N}$ and $\mathrm{P}$ mineralization/immobilization are presented elsewhere (Amacher and others 1999, in press).

\section{Methods}

The aspen restoration treatments were planned and conducted by personnel from the Fishlake and Dixie National Forests, Utah. Main study locations and treatments are listed in table 1. Main study locations are shown in figure 2. The Pole Creek fire on Grindstone and Betenson Flats in June and July 1996 was an 8,000-acre lightning-caused fire that burned a

Table 1-Study sites and aspen regeneration treatments.

\begin{tabular}{|c|c|c|c|c|}
\hline Location & Treatment & $\begin{array}{c}\text { Area of } \\
\text { treatment }\end{array}$ & $\begin{array}{c}\text { Time of } \\
\text { treatment }\end{array}$ & Exclosures \\
\hline \multicolumn{5}{|c|}{ Acres } \\
\hline $\begin{array}{l}\text { South Last Chance, } \\
\text { Fishlake National Forest }\end{array}$ & $\begin{array}{l}\text { Prescribed burn followed } \\
\text { by selective cutting }\end{array}$ & 98 & Spring 1996 & 1 (0.5-acre, four-compartment $\left.{ }^{a}\right)$ \\
\hline $\begin{array}{l}\text { White Ledge, Fishlake } \\
\text { National Forest }\end{array}$ & Clearcut & 117 & $1996-1997$ & $\begin{array}{l}3(10-15 \text { acre, } 4-\mathrm{ft} \\
\text { barbed wire fence) }\end{array}$ \\
\hline $\begin{array}{l}\text { Betenson/Grindstone Flats, } \\
\text { Fishlake National Forest }\end{array}$ & $\begin{array}{l}\text { Pole Creek natural fire } \\
\text { followed by selective } \\
\text { cutting }\end{array}$ & 8,000 & June-July 1996 & 4. (0.5-acre, four-compartment) \\
\hline $\begin{array}{l}\text { Five-Mile Ridge, } \\
\text { Dixie National Forest }\end{array}$ & Prescribed burn & 1,700 & May-June 1996 & None \\
\hline
\end{tabular}

aEach four-compartment exclosure consists of no, low (4ft), high (12 ft), and lay-down (12 ft) fence compartments each measuring $75 \times 75 \mathrm{ft}$. 


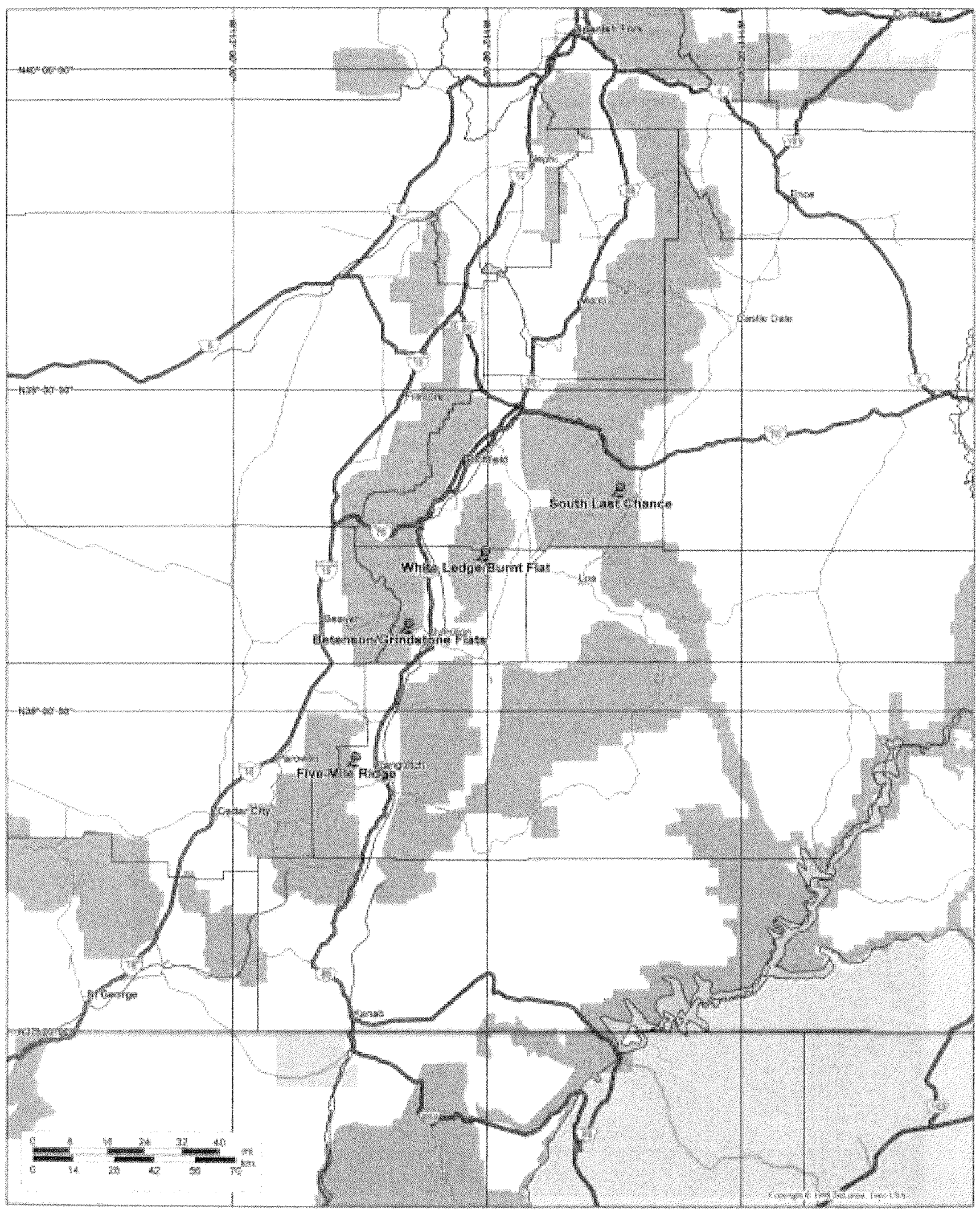

Figure 2-Map of main study sites on Fishlake and Dixie National Forests, Utah. 
mixed aspen/conifer forest. The fires in the Last Chance Creek and Five-Mile Ridge areas were prescribed burns conducted during the spring of 1996. The Last Chance burn was about 100 acres in decadent aspen, while the Five-Mile Ridge burn was about 1,700 acres in mixed aspen/conifer. Some selected cutting was done in the Pole Creek fire area and South Last Chance prescribed burn following the fires. The clearcut (about 120 acres) was done in mixed aspen/conifer in the White Ledge area adjacent to the Burnt Flat Analysis Area.

Following the fires and clearcut, exclosures were erected to control grazing. Three exclosures (about 10 to 15 acres each) of 4 -ft high barbwire fence were begun in the White Ledge clearcut in 1996 and were completed in 1997. Two four-compartment exclosures were built in the burn areas of the Last Chance watershed during the summer of 1996 . Four fourcompartment exclosures were begun in the burn areas of Grindstone Flat and Betenson Flat in 1996 and were completed in 1997. At the time this study was done, the Five-Mile Ridge burn area had no exclosures.

Each four-compartment exclosure consists of an unfenced compartment, a low (4-ft) fence compartment, a high (8-ft) fence compartment, and a compartment with a 8-ft lay-down fence, which could be set up and taken down to control grazing access (fig. 3). Each compartment measures $75 \times 75 \mathrm{ft}$ and is built of wire mesh strung between cedar and steel fence posts.

\section{Soil Temperature Measurements}

We used Optic StowAway temperature sensors/data loggers with $8 \mathrm{~K}$ of memory to collect and record soil temperature data automatically. The temperature range of these sensors is -5 to $37^{\circ} \mathrm{C}$ and accuracy is $\pm 0.2^{\circ} \mathrm{C}$. The temperature loggers are waterproof to a submerged depth of $100 \mathrm{ft}$.

We set the temperature loggers to collect hourly temperature data, and launched them according to the manufacturer's instructions. The loggers were buried in the soil to a depth of $10 \mathrm{~cm}$. This corresponded to the depth at the bottom of the soil cores we used to measure $\mathrm{N}$ and $\mathrm{P}$ mineralization/immobilization (Amacher and others 1999).

Chaining pins were used to mark the locations of the loggers. Because we had a limited number of temperature loggers for the first year, we focused on measuring soil temperature in treated mixed aspen/conifer stands and in similar untreated stands. Twelve loggers were installed in June 1997. Four additional loggers were installed in July 1997 to obtain more data in untreated areas.

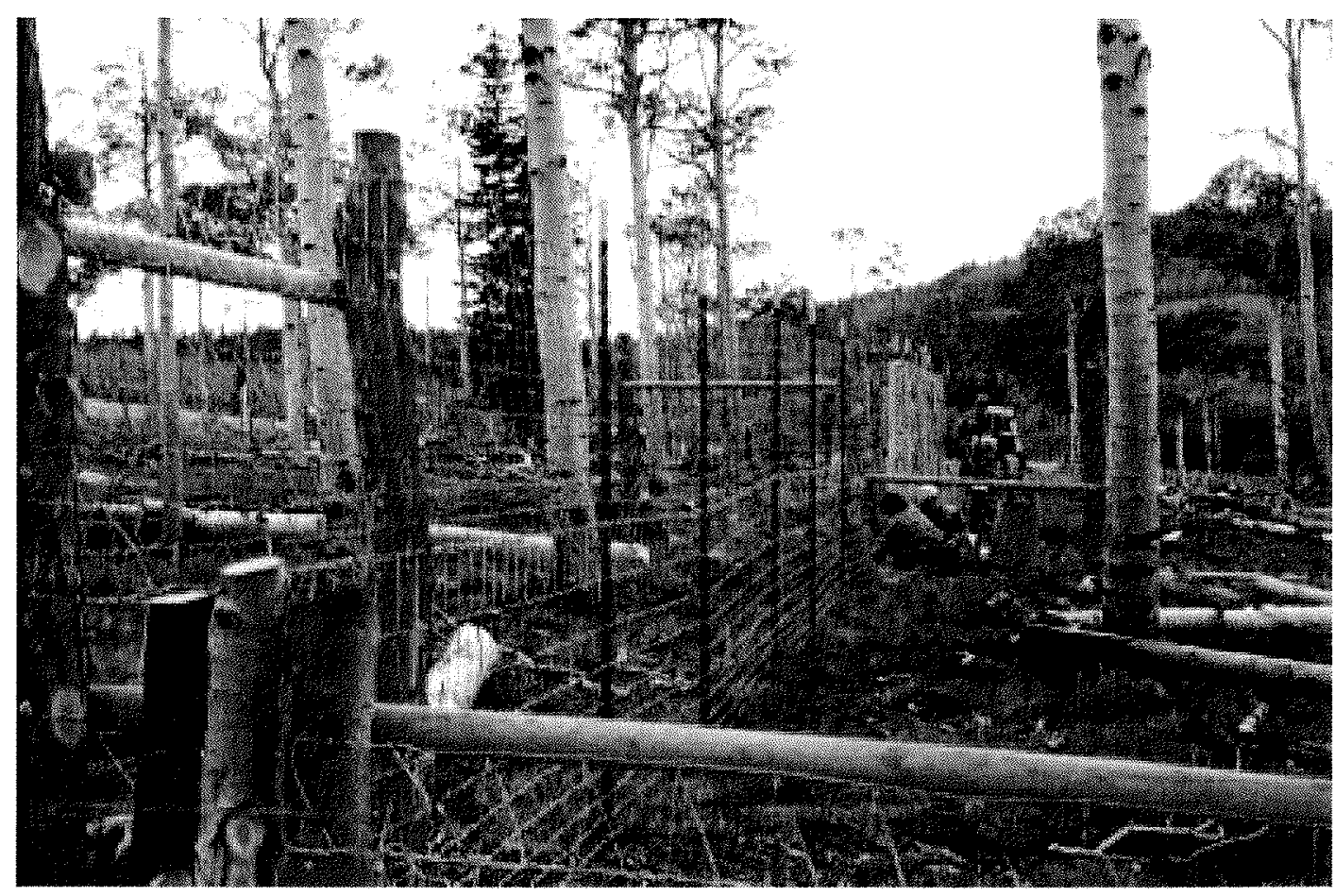

Figure 3-The South Last Chance exclosure under construction in July 1996. The low fence to exclude domestic livestock is in the immediate foreground. The high fence to exclude all ungulates is in the background. Photo by Nate Yorgason. 
Locations, stand types, treatments, elevations, and aspects of the sites where the loggers were installed are in table 2. The Five-Mile Ridge site was abandoned in July 1997 because it is not easily accessible and did not have any exclosures. Loggers at the other locations were retrieved in September 1997. Because the chaining pins were removed, the logger at the Burnt Flat stable aspen site was located in September 1998 using a metal detector, but the other logger at Betenson Flat has not been found.

\section{Data Analysis}

After retrieving the loggers, the hourly temperature data were downloaded into spreadsheet files and plotted versus Julian day for each complete data set. Hourly temperature data were also plotted versus time of day for selected days. Box plots that display the $25^{\text {th }}$ and $75^{\text {th }}$ percentiles as a box centered about the $50^{\text {th }}$ percentile (median), the $10^{\text {th }}$ and $90^{\text {th }}$ percentiles as error bars, and the $5^{\text {th }}$ and $95^{\text {th }}$ percentiles as points were constructed from the complete data set for each logger. A t-test was conducted to compare mean summertime soil temperatures in treated (cut or burned) versus untreated mixed aspen/conifer stands. A oneway analysis of variance and mean comparisons test (Tukey's) was used to compare mean summertime soil temperatures in untreated mixed aspen/conifer stands with those in untreated aspen (decadent and stable) and treated (cut or burned) mixed aspen/conifer stands. Overlay and difference plots were used to compare daily mean soil temperatures in different stand types and treatment combinations. A mixed model with an autocorrelation function was used to analyze the effects of stand type (aspen or mixed aspen/conifer), treatment (none or treated [cut or burned]), and time on daily mean soil temperature (Littell and others 1996).

\section{Results}

The temperature loggers were deployed in late June 1997, a few days after the summer solstice. Before then, the sites were generally inaccessible because of remaining snowpack and impassable roads. The June 1997 to May 1998 soil temperature profile for the stable aspen site on Burnt Flat indicated that soil warming did not begin until May at this elevation and exposure (fig. 4). Root growth and leaf development also began at this time. The temperature loggers were deployed in the middle to late part of the soil warming period. Slow soil cooling appeared to take place in late summer and rapid soil cooling began in the fall. The ground eventually froze under the snowpack in January (fig. 4). The temperature loggers at the other sites were removed about the middle to near the end of the slow cooling period. Summertime soil temperature profiles for all sites are shown in appendix figures A1 to A4.

\section{Hourly Soil Temperatures Profiles}

Hourly soil temperature profiles on selected days at several locations are shown in figures 5 to 8 . These figures show more detail in the soil temperature profile for a given day than figures A1 to A4. The time of day that the soil temperature reaches the maximum or minimum on a given day can be determined using figures 5 to 8 .

At Five-Mile Ridge on June 29, 1997, soil under the burned conifer warmed faster and reached a higher

Table 2-Stand types, elevations, and aspects of study sites where temperature sensors were located.

\begin{tabular}{|c|c|c|c|c|c|}
\hline Location & Latitude/Longitude & Stand type & Treatment & Elevation & Aspect \\
\hline & & & & feet & \\
\hline South Last Chance & N38E39.23' W111E30.26' & Decadent aspen & Prescribed burn & 9,900 & NE \\
\hline White Ledge exclosure 1 & N38E27.90'W112E04.05' & Mixed aspen/conifer & Cut & 9,600 & SSW \\
\hline White Ledge & N38 27.59' W112 03.73' & Mixed aspen/conifer & None & 9,600 & NE \\
\hline Burnt Flat (Rt. 070) & N38 25.74' W112 01.77' & Mixed aspen/conifer & None & 9,400 & $N E$ \\
\hline Langdon Mountain & N38 24.41' W112 00.94' & Mixed aspen/conifer & None & 9,500 & NNW \\
\hline Burnt Flat (Rt. 068) & N38 26.21' W112 01.34' & Decadent aspen & None & 9,100 & $E$ \\
\hline Burnt Flat (site 1) & N38 $29.57^{\prime} W 11159.83^{\prime}$ & Stable aspen & None & 9,100 & SSE \\
\hline Betenson exclosure 1 & N38 13.51' W112 21.81' & Mixed aspen/conifer & Natural fire & 9,900 & WSW \\
\hline Betenson exclosure 2 & N38 13.25'W112 21.91' & Mixed aspen/conifer & Natural fire & 9,900 & WSW \\
\hline Grindstone exclosure 1 & N38 15.11'W112 20.08' & Mixed aspen/conifer & Natural fire & 9,600 & W \\
\hline Grindstone exclosure 2 & N38 14.94' W112 20.29' & Mixed aspen/conifer & Natural fire & 9,500 & WNW \\
\hline Betenson Flat & N38 13.56' W112 22.45' & Mixed aspen/conifer & None & 9,900 & NE \\
\hline Betenson/Grindstone Flats & N38 $14.55^{\prime} W+1221.12^{\prime}$ & Young aspen & None & 9,600 & WNW \\
\hline Betenson/Grindstone Flats & N38 14.54' W112 21.09' & Mixed aspen/conifer & None & 9,700 & WNW \\
\hline Five-Mile Ridge & N37 $49.80^{\prime}$ W112 33.62' & Decadent aspen & None & 8,900 & ESE \\
\hline Five-Mile Ridge & N37 49.80' W112 33.62' & Mixed aspen/conifer & Prescribed burn & 8,900 & ESE \\
\hline
\end{tabular}




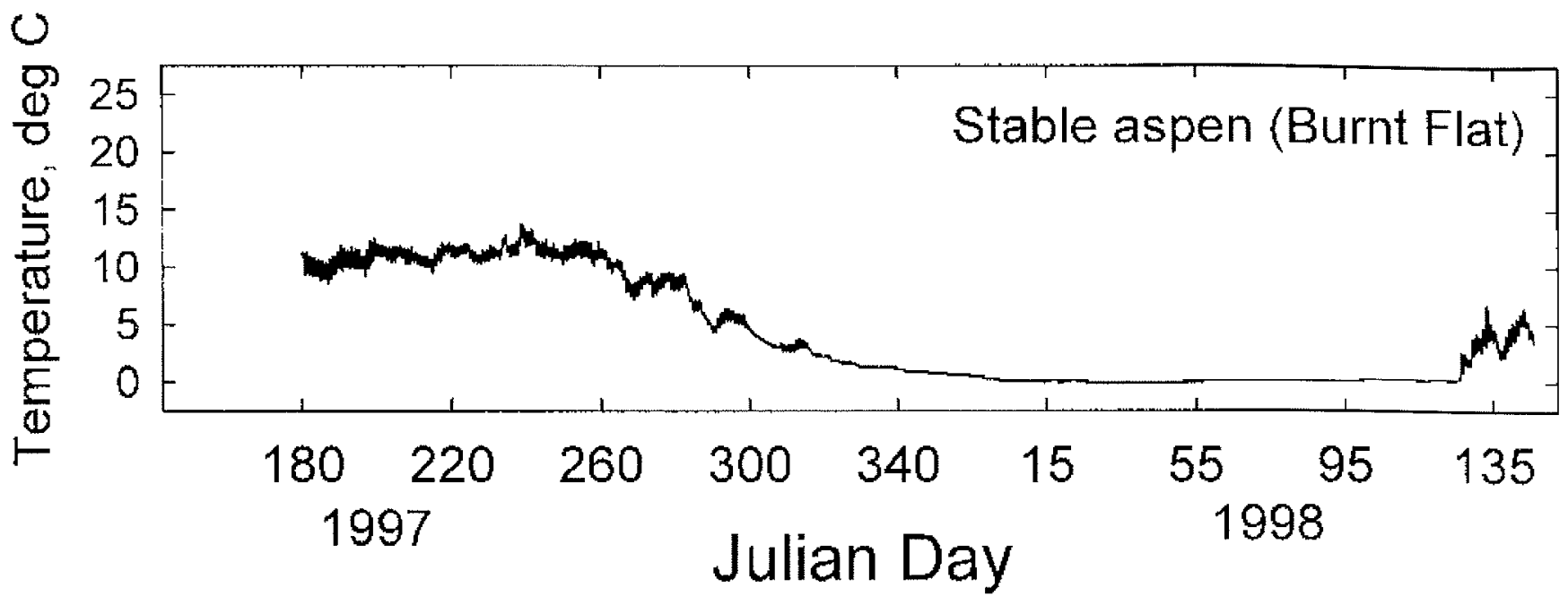

Figure 4-Hourly soil temperatures (10-cm depth) from June 1997 to May 1998 under stable aspen at Burnt Flat, Fishlake National Forest.

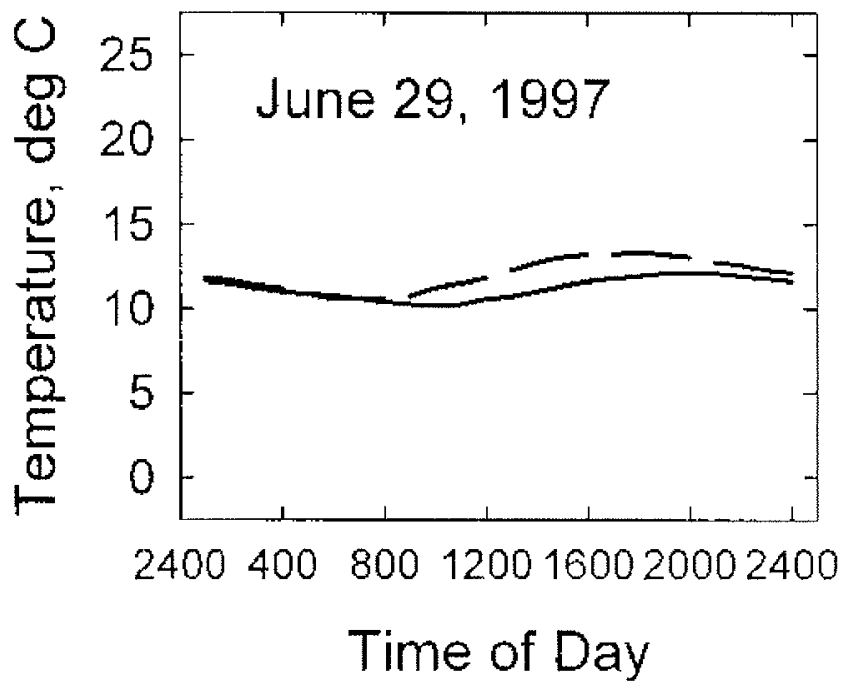

Solid line: Unburned aspen Dashed line: Burned conifer

Figure 5-Hourly soiltemperatures (10-cm depth) on June 29, 1997, under unburned decadent aspen and burned conifer on Five-Mile Ridge, Dixie National Forest.

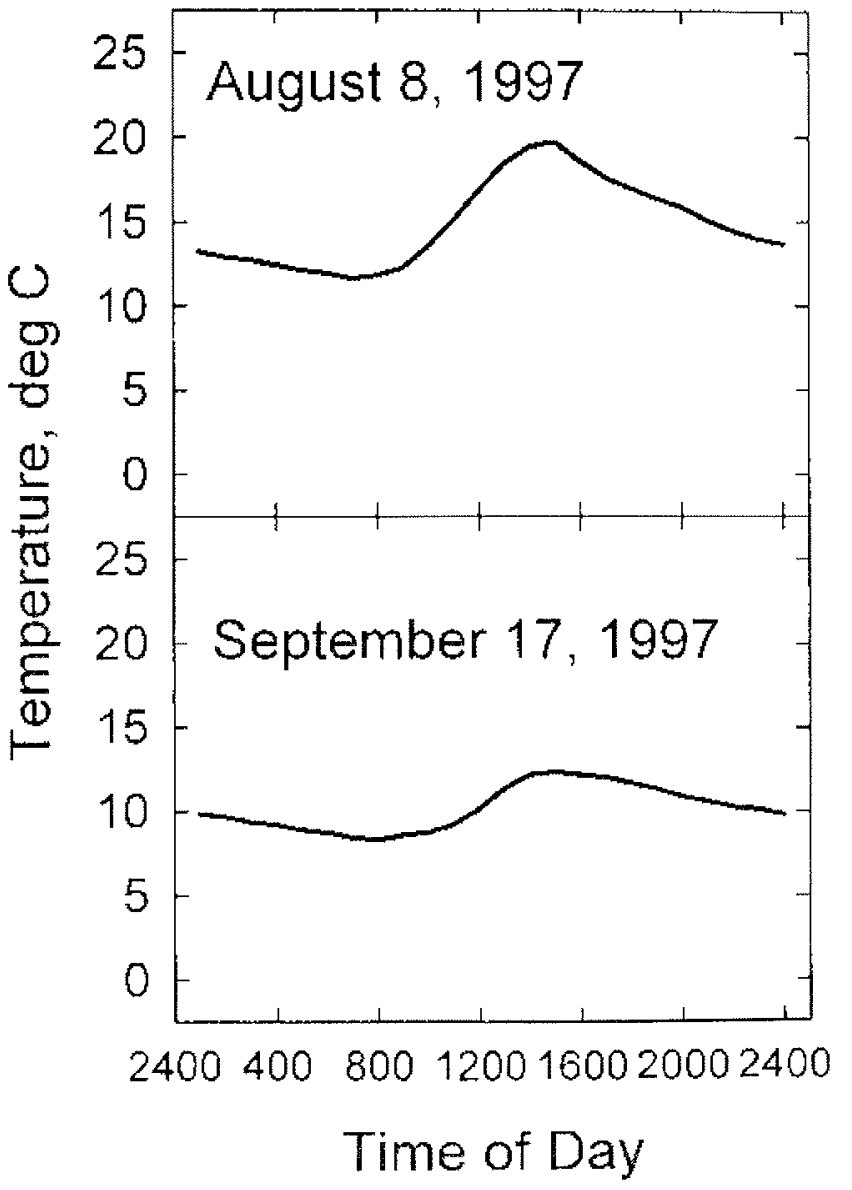

Figure 6-Hourly soil temperatures (10-cm depth) on August 8, 1997, and September 17, 1997, under burned and cut decadent aspen in South Last Chance exclosure, Fishlake National Forest. 


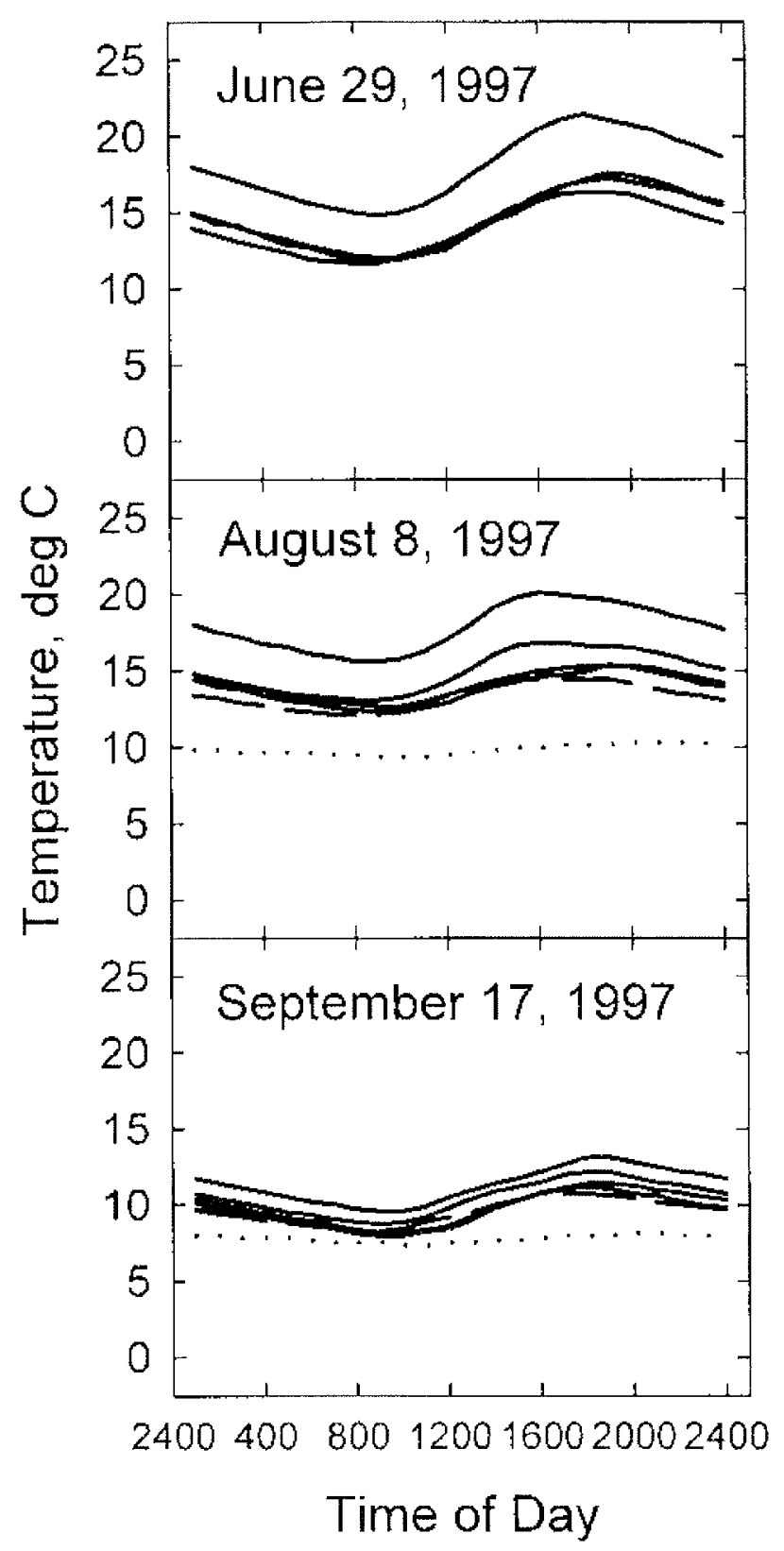

Solid lines: Burned aspen/conifer

Dashed line: Stable aspen Dotted line: Unburned aspen/conifer

Figure 7-Hourly soil temperatures (10-cm depth) on June 29, 1997, August 8, 1997, and September 17,1997 , under burned and cut aspen/conifer in Betenson and Grindstone Flat exclosures and stable aspen and untreated aspen/conifer between Betenson and Grindstone Flats, Fishlake, National Forest.

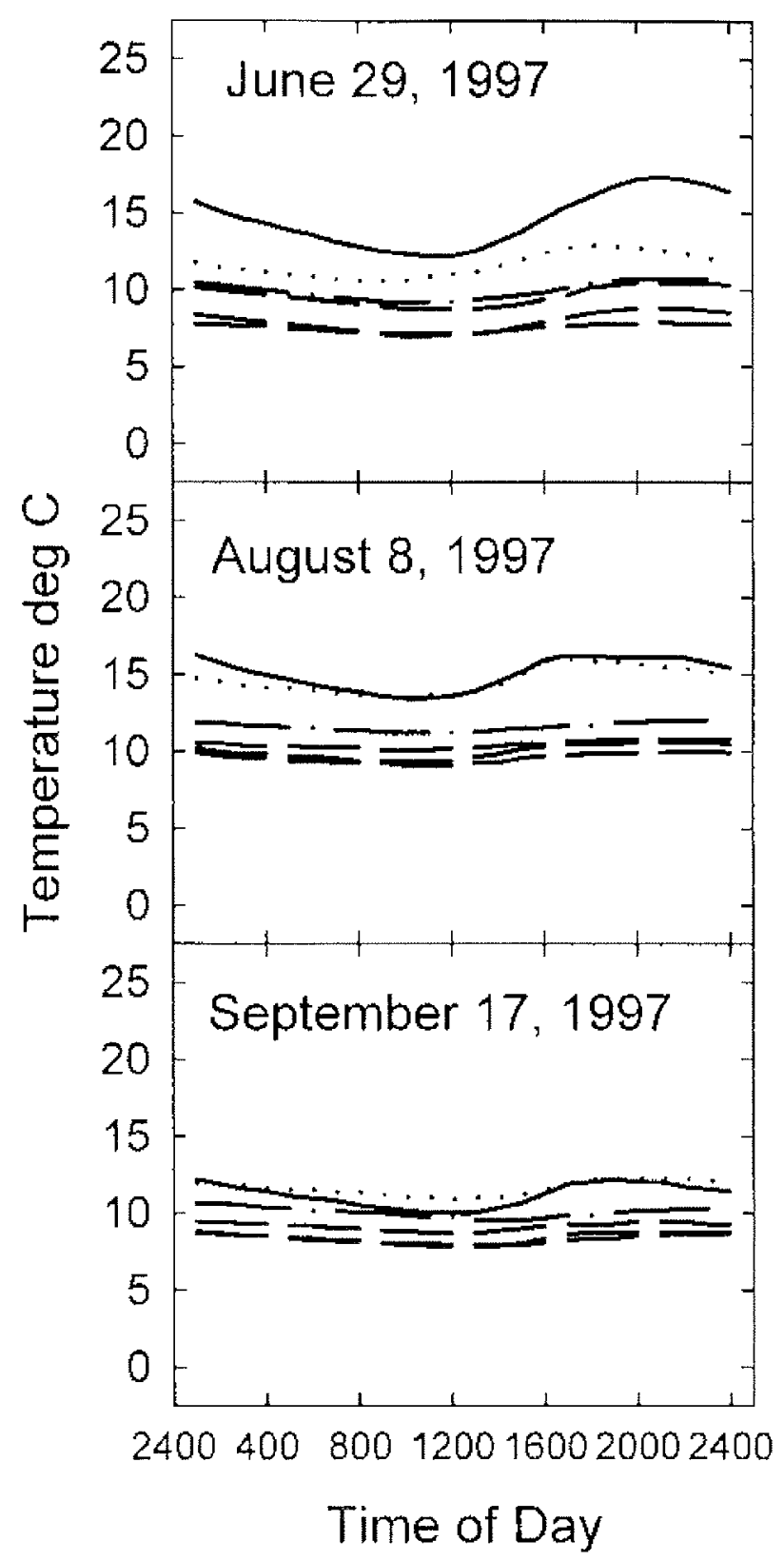

Solid line: Clearcut aspen/conifer Dashed lines: Untreated aspen/conifer Dotted line: Decadent aspen Dash-dot line: Stable aspen

Figure 8-Hourly soiltemperatures(10-cm depth) on June 29, 1997, August 8,1997 , and September 17,1997 , under clearcut and untreated aspen/ conifer at White Ledge; untreated aspen/conifer at Langdon Mountain; and untreated aspen/ conifer, decadent aspen, and stable aspen at Burnt Flat, Fishlake National Forest. 
maximum temperature than under unburned aspen, although the differences were small (fig. 5). During the morning hours, soil temperature under both stands was similar. However, in late morning, soil temperature under burned conifer began to increase because of heat trapped by the dark-colored burned conifer needles and reached a maximum in late afternoon. In contrast, soil temperature under untreated aspen did not begin to warm until noon and did not reach a maximum until the evening hours. Both of these sites had the same elevation and aspect and were located within $500 \mathrm{ft}$ of each other (table 2).

At South Last Chance (burned and cut decadent aspen), maximum soil temperatures were reached in mid-afternoon (fig. 6). At Betenson and Grindstone Flats, soil temperature profiles for Betenson exclosure 1 and the two Grindstone exclosures were almost identical on June 29, 1997, and reached a maximum in early evening (fig. 7). Soil temperature in Betenson exclosure 2 was significantly warmer than in the other exclosures and reached a maximum temperature in late afternoon. On August 8, 1997, soil temperature profiles for Betenson exclosure 1 and Grindstone exclosure 1 were still nearly identical, with an early evening maximum. Soil temperature in Grindstone exclosure 2 increased faster in the afternoon than in Betenson and Grindstone exclosures 1 and reached maximum in late afternoon. Soil temperature in Betenson exclosure 2 continued higher than those in the other exclosures and reached a maximum in late afternoon. By late summer (September 17, 1997), soil temperature profiles in all four exclosures were similar with maximum temperatures were reached in the evening. Soil temperature in a young aspen stand (regenerated as a result of a 1958 fire on Betenson Flat) was similar to that in three of the exclosures. Soil temperature in the unburned aspen/conifer showed little diurnal fluctuation and did not reach a maximum until late evening. The four exclosures, the stable aspen, and the unburned aspen/conifer all had similar westerly aspects and were at similar elevations (table 2).

At White Ledge and Burnt Flat on June 29, 1997, soil temperature was highest in the clearcut area compared to the other sites and reached a maximum in the evening (fig. 8). Soil temperature under decadent aspen reached a maximum in late afternoon, whereas the other sites did not reach their maximum temperature until the evening hours. On August 8, 1997, soil temperature profiles in the clearcut and decadent aspen were similar with maximums in the late afternoon. The other sites showed less diurnal fluctuation and continued to have maximum temperatures in the evening. By late summer (September 17, 1997), soil temperature differences among the sites decreased, but the untreated aspen/conifer sites continued to reach their maximum temperatures later in the day than did the clearcut and decadent aspen sites. Throughout the summer, soil temperatures under untreated aspen/conifer were almost always lower than those under the clearcut or aspen sites. The aspen/conifer sites (both clearcut and untreated) are at higher elevations $(9,400$ to $9,600 \mathrm{ft})$ than the decadent or stable aspen sites $(9,100 \mathrm{ft})$, which are surrounded by sagebrush. All the untreated aspen/conifer sites had northerly exposures, while the clearcut and aspen (decadent and stable) had southerly or easterly exposures.

The time of day that soil temperatures reach their maximum appears more related to plant cover than to elevation or aspect. Soil temperature in treated stands with little remaining canopy (whether burned or cut, regardless of location) and stands with a sparse canopy (decadent aspen on Burnt Flat) usually reached a maximum in late afternoon. Soil temperature in untreated aspen/conifer did not reach a maximum until the evening hours. Although a small shift in the time of day of the maximum soil temperature existed in some treated stands as summer progressed, there was little if any shift in the time of day of the maximum temperature in untreated aspen/conifer.

\section{Effects of Stand Type and Treatment on Soil Temperature Ranges, Medians, and Means for the Entire Summer}

The effects of stand type and treatment on the distribution of summertime soil temperatures are illustrated in figures 9,10 , and 11. At all locations, treated stands had a greater range of summertime soil temperatures than did untreated stands, and median values in treated stands were greater than those in untreated stands.

The mean summertime soil temperature for all treated stands (burned or clear-cut) was significantly greater than that for all untreated (table 3 ) and untreated aspen/conifer (excluding decadent and stable aspen) stands (table 4). Mean summertime soil temperature for untreated aspen (decadent and stable) was also significantly greater than that of untreated mixed aspen/conifer stands (table 5).

\section{Effects of Stand Type and Treatments on Daily Mean Soil Temperatures}

We used overlay and difference plots to compare daily mean, maximum, and minimum soil temperatures under the different stand types and treated areas. When overlaid on the same plot, daily mean soil temperatures under burned aspen/conifer on Betenson/ Grindstone Flats were higher than unburned stands throughout the summer (fig. 12). In contrast, daily 


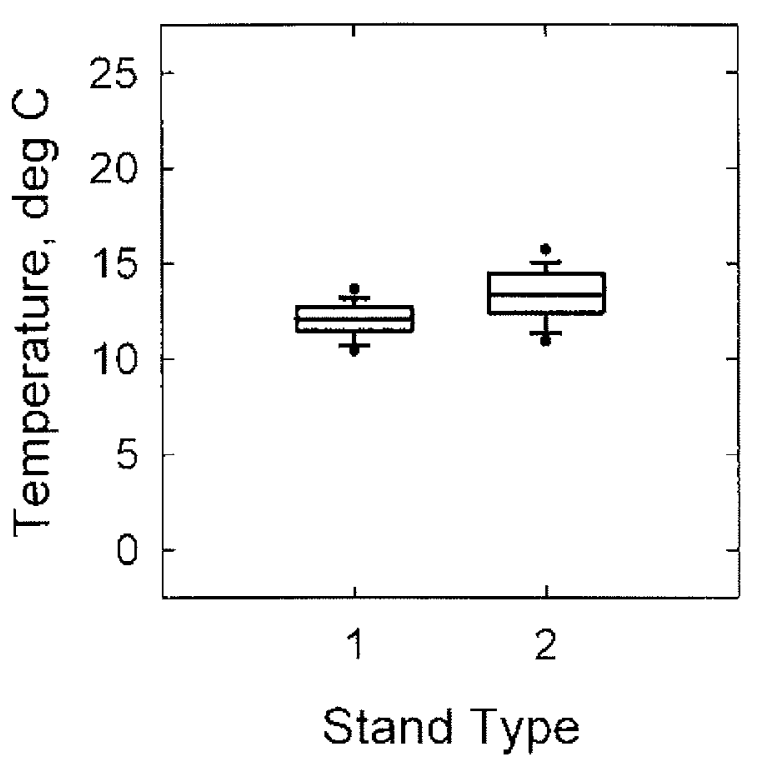

$$
\begin{aligned}
& 1=\text { Unburned aspen } \\
& 2=\text { Burned conifer }
\end{aligned}
$$

Figure 9-Box plot of hourly summertime (June 25, 1997, to July 20, 1997) soil temperatures (10-cm depth) under unburned decadent aspen and burned conifer on FiveMile Ridge, Dixie National Forest. The $25^{\text {th }}$ and $75^{\text {th }}$ percentiles are shown as a box centered about the $50^{\text {th }}$ percentile, the $10^{\text {th }}$ and $90^{\text {th }}$ percentiles are shown as error bars, and the $5^{\text {th }}$ and $95^{\text {th }}$ percentiles are shown as points.
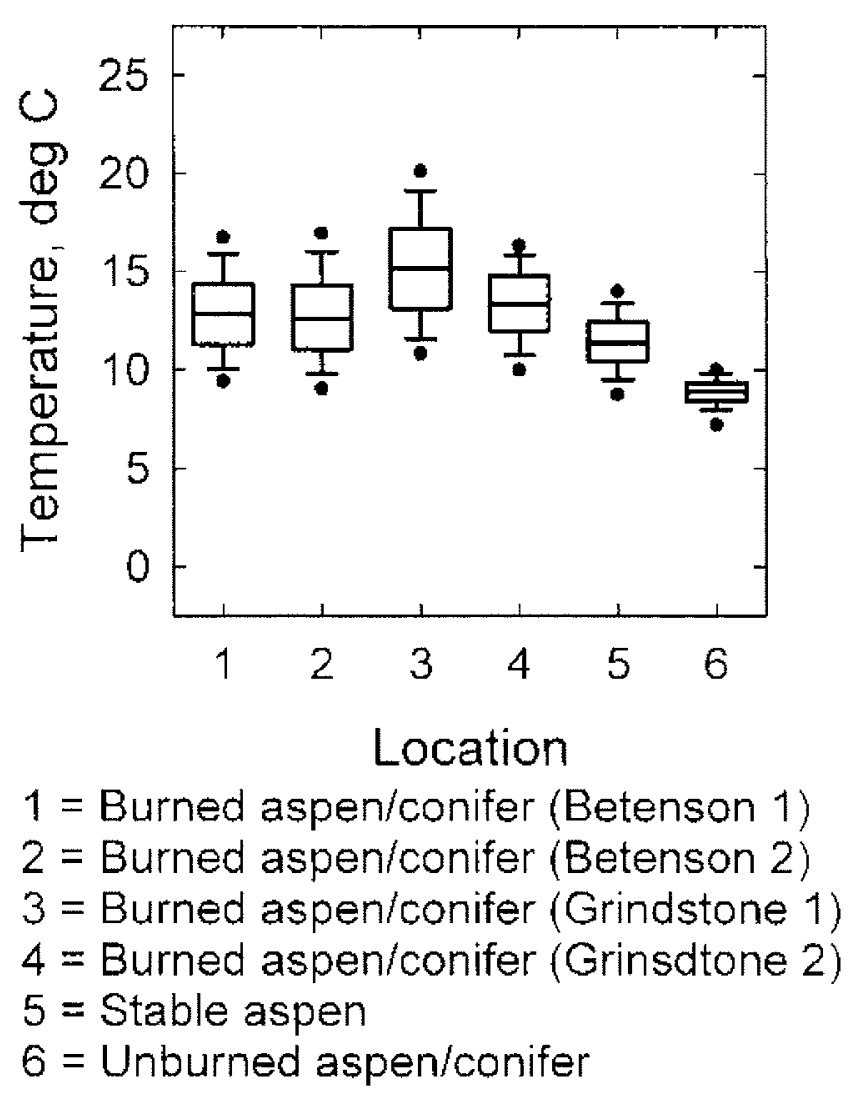

Figure 10-Box plot of hourly summertime (June 25, 1997, to September 22, 1997) soil temperatures $(10-\mathrm{cm}$ depth) under burned and cut aspen/conifer in Betenson and Grindstone Flat exclosures and stable aspen and untreated aspen/conifer between Betenson and Grindstone Flats, Fishlake National Forest. The $25^{\text {th }}$ and $75^{\text {th }}$ percentiles are shown as a box centered about the $50^{\text {th }}$ percentile, the $10^{\text {th }}$ and $90^{\text {th }}$ percentiles are shown as error bars, and the $5^{\text {th }}$ and $95^{\text {th }}$ percentiles are shown as points.

temperature under stable aspen increased to above that under untreated aspen/conifer.

Difference plots revealed increasing or decreasing differences among soil temperatures under the different stand types and treated areas as summer progressed. At Five-Mile Ridge where soil temperature was measured from June 25 to July 20 , differences between daily mean, maximum, and minimum soil temperatures under burned conifer and corresponding soil temperatures under decadent aspen increased as summer progressed (fig. 14). At Betenson/Grindstone Flats, differences between daily mean, maximum, and minimum soil temperatures under burned aspen/conifer and corresponding soil temperatures 


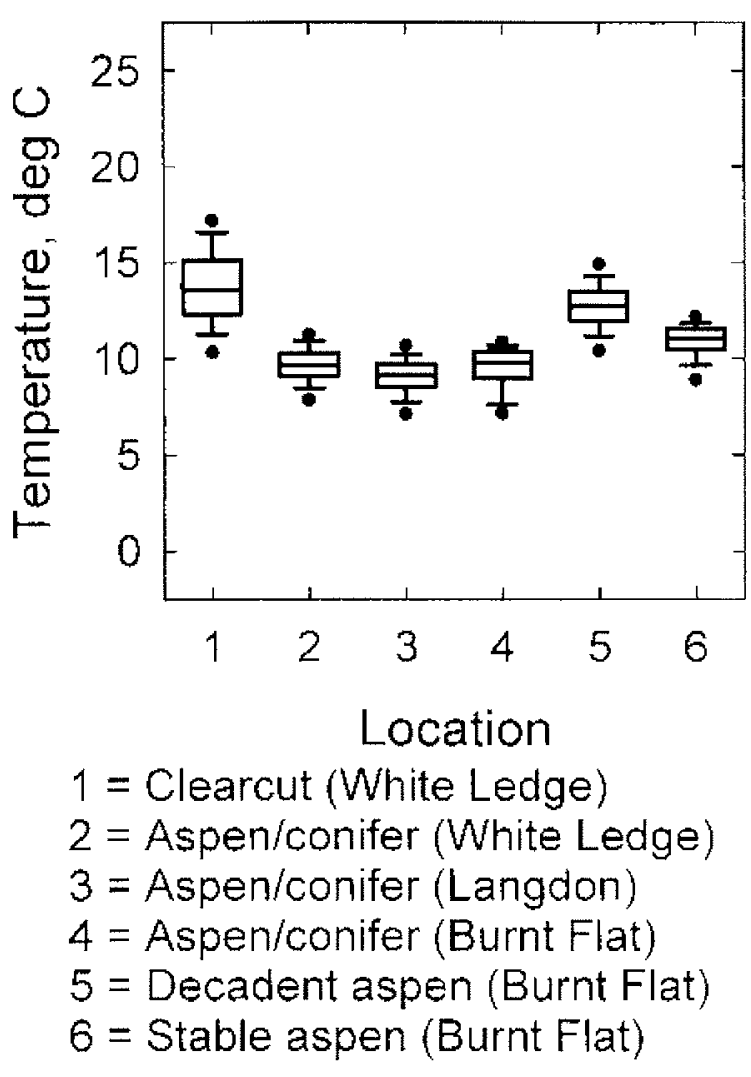

Figure 11-Box plot of hourly summertime (June 27, 1997, to September 23, 1997) soil temperatures (10-cm depth) under clearcut and untreated aspen/conifer at White Ledge; untreated aspen/conifer at Langdon Mountain; and untreated aspen/conifer, decadent aspen, and stable aspen at Burnt Flat, Fishlake National Forest. The $25^{\text {th }}$ and $75^{\text {th }}$ percentiles are shown as a box centered about the $50^{\text {th }}$ percentile, the $10^{\text {th }}$ and $90^{\text {th }}$ percentiles are shown as error bars, and the $5^{\text {th }}$ and $95^{\text {th }}$ percentiles are shown as points.
Table 3-Comparison of mean summertime soil temperatures for all untreated stands (decadent and stable aspen and mixed aspen/conifer) with all treated (cut or burned) stands (decadent aspen and mixed aspen/ conifer).

\begin{tabular}{|c|c|c|c|}
\hline & $\begin{array}{c}\text { Number of } \\
\text { stands }\end{array}$ & $\begin{array}{c}\text { Mean soil } \\
\text { temperature }\end{array}$ & SEM $^{\mathrm{a}}$ \\
\hline & & $\operatorname{Deg} C$ & \\
\hline Untreated stands & 8 & $10.49 \mathrm{a}^{\mathrm{b}}$ & 0.51 \\
\hline Treated stands & 7 & $13.35 \mathrm{~b}$ & 0.36 \\
\hline
\end{tabular}

astandard error of the mean.

bMeans not followed by the same letter are significantly different according to the t-test $(p=0.001)$.

Table 4-Comparison of mean summertime soil temperatures for untreated mixed aspen/conifer stands with treated (cut or burned) mixed aspen/conifer stands.

\begin{tabular}{lccr}
\hline & $\begin{array}{c}\text { Number of } \\
\text { stands }\end{array}$ & $\begin{array}{c}\text { Mean soil } \\
\text { temperature }\end{array}$ & SEM $^{\mathrm{a}}$ \\
\hline $\begin{array}{l}\text { Untreated } \\
\text { aspen/conifer }\end{array}$ & 4 & $\begin{array}{c}\text { Deg C } \\
9.25 \mathrm{a}^{\mathrm{b}}\end{array}$ & 0.18 \\
$\begin{array}{l}\text { Treated } \\
\text { aspen/conifer }\end{array}$ & 7 & $13.35 \mathrm{~b}$ & 0.36 \\
\hline
\end{tabular}

aStandard error of the mean.

bMeans not followed by the same letter are significantly different according to the t-test $(p<0.001)$.

Table 5-Comparison among mean summertime soil temperatures for untreated aspen (decadent and stable) stands, untreated mixed aspen/conifer stands, and treated (cut or burned) stands (decadent aspen and mixed aspen/conifer).

\begin{tabular}{lccc}
\hline & $\begin{array}{c}\text { Number of } \\
\text { stands }\end{array}$ & $\begin{array}{c}\text { Mean soil } \\
\text { temperature }\end{array}$ & SEM $^{\text {a }}$ \\
\hline $\begin{array}{l}\text { Untreated } \\
\quad \text { aspen/conifer }\end{array}$ & 4 & $\begin{array}{c}\text { Deg C } \\
9.25 \mathrm{a}^{\mathrm{b}}\end{array}$ & 0.18 \\
$\begin{array}{l}\text { Untreated aspen } \\
\text { Treated stands }\end{array}$ & 4 & $11.73 \mathrm{~b}$ & 0.38 \\
\hline
\end{tabular}

a Standard error of the mean.

b Means not followed by the same letter are significantly different by the Tukey test $(p<0.001)$. 


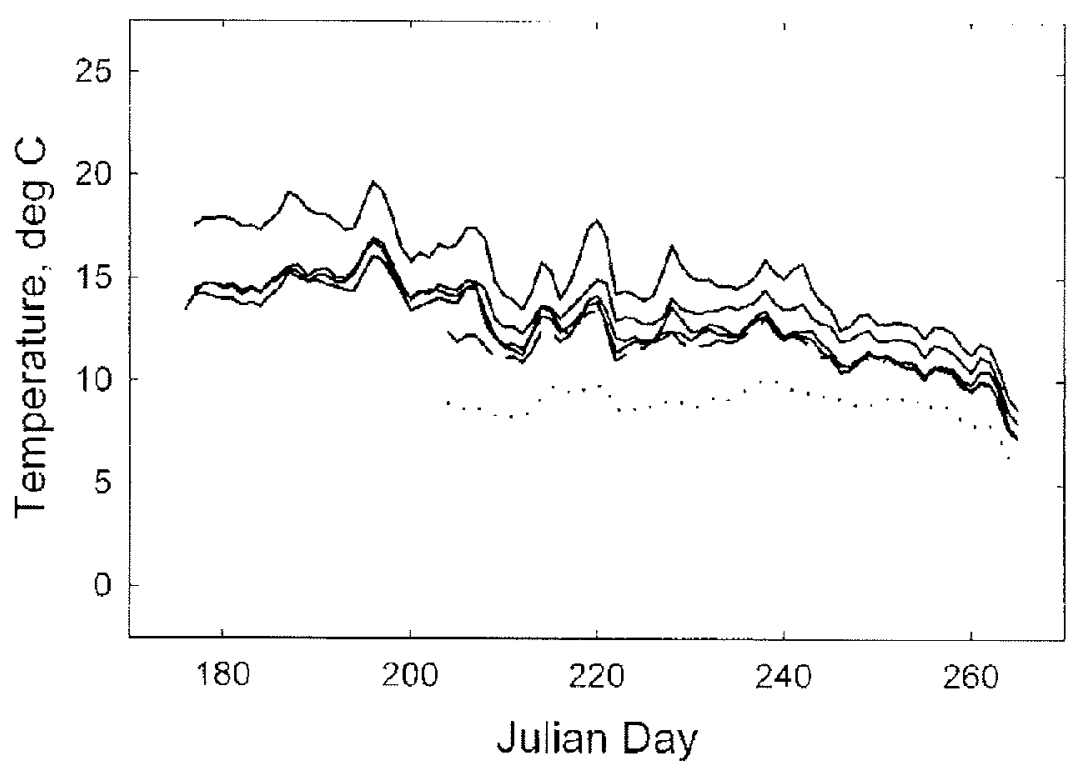

Solid lines: Burned aspen/conifer Dashed line: Stable aspen

Dotted line: Unburned aspen/conifer

Figure 12-Overlay plots comparing daily mean summertime soil temperatures under burned and cut aspen/coniferin Betenson and Grindstone Flat exclosures (solid lines), stable aspen (dashed line), and unburned aspen/conifer (dotted line).

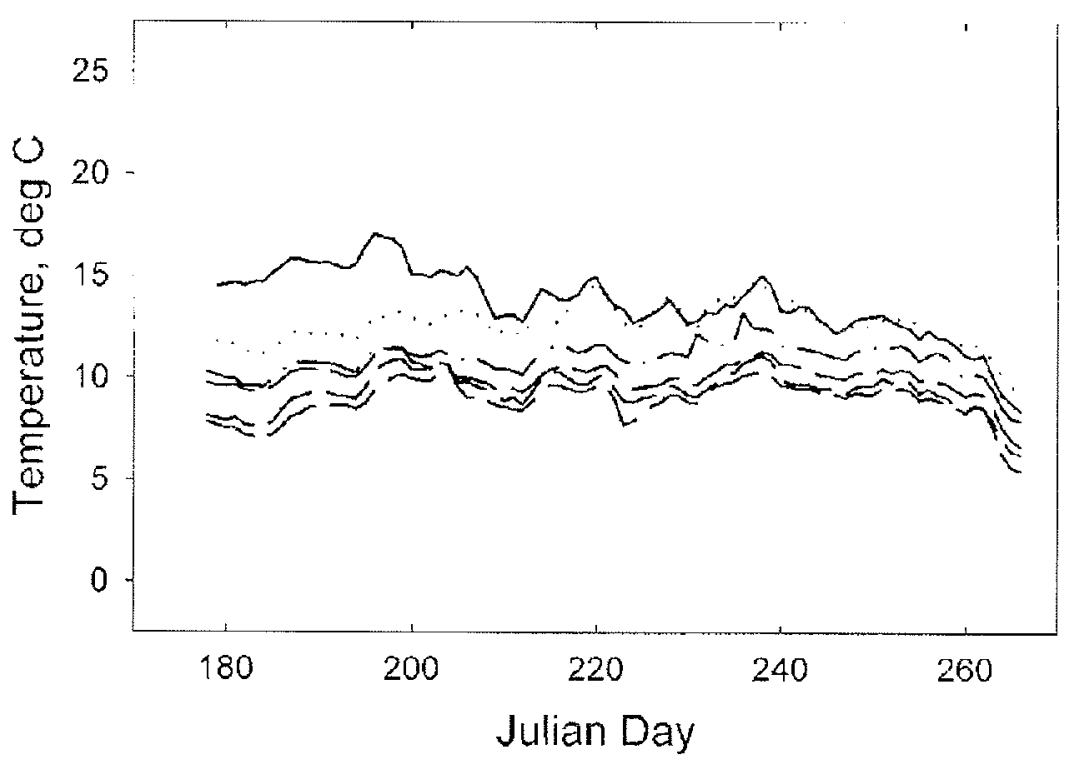

Solid line: Clearcut aspen/conifer

Dashed lines: Untreated aspen/conifer Dotted line: Decadent aspen Dash-dot line: Stable aspen

Figure 13-Overlay plots comparing daily mean summertime soil temperatures under clearcut aspen/conifer at White Ledge (solid line), untreated aspen/conifer at White Ledge, Langdon Mountain, and Burnt Flat (dashed lines), and decadent (dotted line) and stable aspen (dash-dot line) at Burnt Flat. 


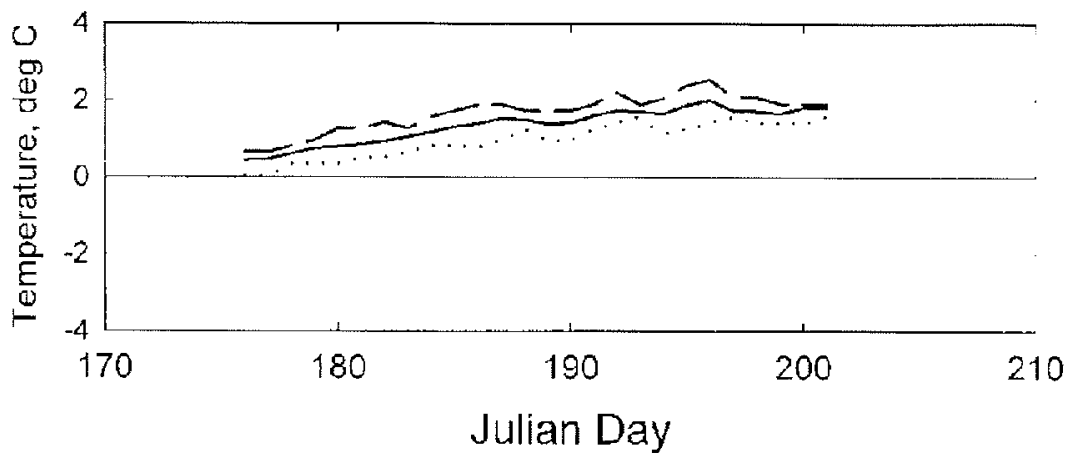

Dashed line: Maximum

Solid line Mean

Dotted line: Minimum

Figure 14-Difference plots obtained by subtracting daily mean, maximum, and minimum summertime soil temperatures under unburned decadent aspen from their corresponding values under burned conifer at Five-Mile Ridge, Dixie National Forest.

under unburned aspen/conifer were greater in early summer, but these differences decreased as summer progressed (fig. 15). A similar response was observed at the White Ledge and Burnt Flat sites. When daily mean, maximum, and minimum soil temperatures under untreated aspen/conifer were subtracted from corresponding soil temperatures under clearcut aspen, decadent aspen, and stable aspen, differences were greater in early summer and decreased as summer progressed (fig. 16).

\section{Nonlinear Regression Analysis}

Relationships between daily mean soil temperature and time expressed as Julian days followed a quadratic function. In figures 17 to 20 , daily mean soil temperatures were plotted as filled circles, the quadratic regression equations as solid lines, and the $95 \%$ confidence intervals around the regression equations as dotted lines. Increasing, stable, or decreasing temperature trends were seen as summer progressed depending on location, treatment, and stand type. These plots were used to delineate overall periods of heating or cooling.

In treated areas, mean daily soil temperatures increased until mid July (Betenson and Grindstone exclosures, White Ledge clearcut) or early August (South Last Chance), then decreased the remainder of the summer. In most untreated areas, mean daily soil temperatures increased until late August (Betenson/ Grindstone Flats unburned aspen/conifer, and all Burnt Flat sites), then decreased. In the Betenson/Grindstone Flats young aspen and White Ledge and Langdon. Mountain untreated aspen/conifer, mean daily soil temperatures increased until late July to early August, then decreased. However, rates of mean daily soil temperature decrease in the White Ledge and Langdon Mountain untreated aspen/conifer sites from late July to late September were small. This is because mean daily soil temperature from late July to late August was largely unchanged at these sites, and most of the temperature decrease was from late August to late September, as was the case at the other untreated sites.

Daily mean soil temperatures at all sites were used to develop predicted regression equations for daily mean soil temperature as a function of time for untreated aspen (stable and decadent), treated (burned and cut) decadent aspen, untreated aspen/conifer, and treated (cut or burned and cut) aspen/conifer (fig. 21). Regression coefficients for the different stand type and treatment combinations are presented in table 6 . Untreated sites are expected to have symmetrical daily mean soil temperature curves peaking at a maximum in early to mid August. In contrast, daily mean soil temperatures in treated areas are expected to be higher in early summer when solar radiation and solar angle are at a maximum and then decrease through the summer as solar radiation and angle decrease and developing plant canopies provide shading.

\section{Discussion}

Soils underneath mixed aspen/conifer stands with more than $50 \%$ conifers are insulated by a litter layer of conifer needles and branches in various stages of decomposition. Also, the soils are shaded by a thick canopy of mixed aspen and conifer. Thus, these soils 


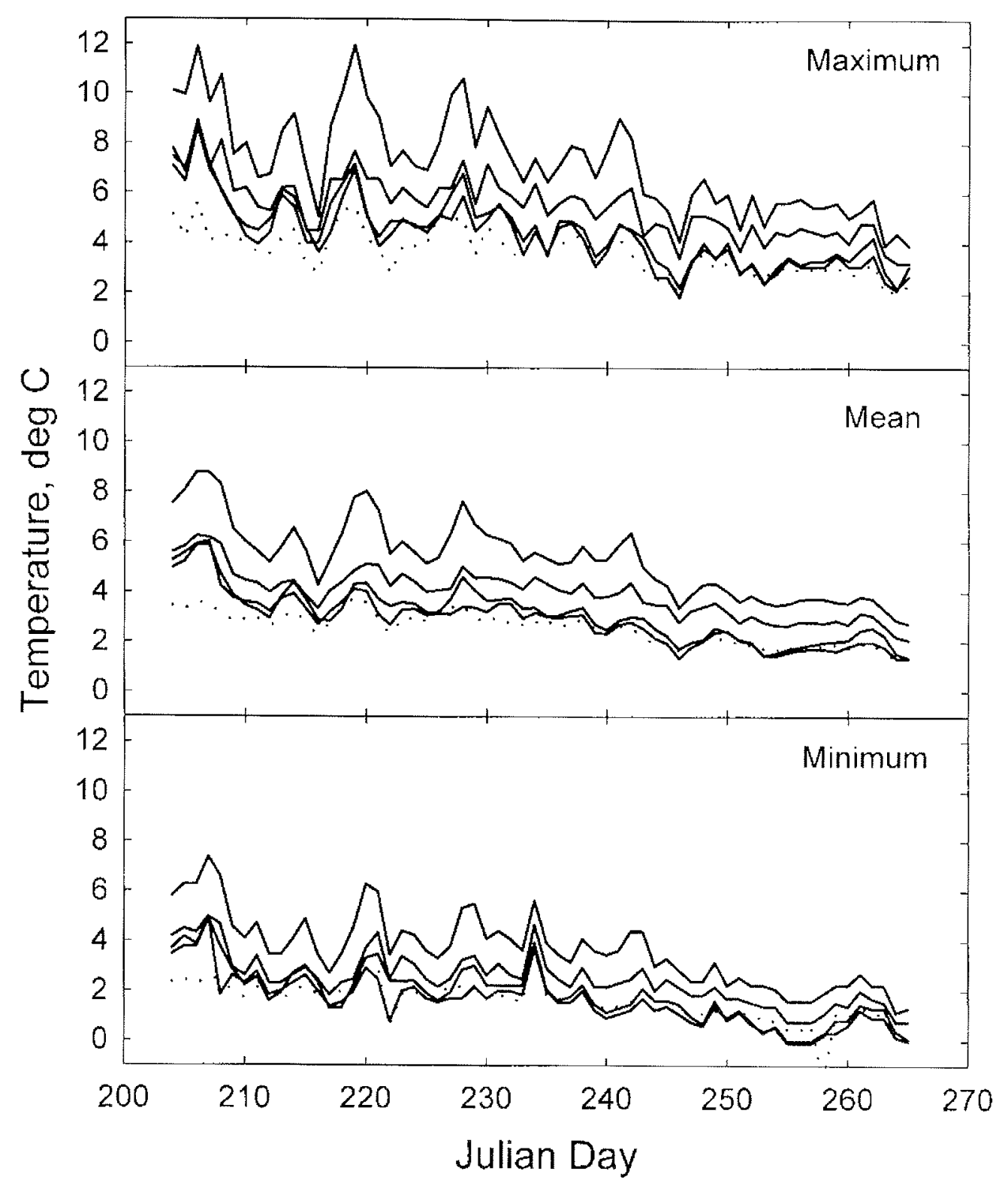

Solid lines: Burned aspen/conifer - Unburned aspen/conifer

Dotted line: Stable aspen - Unburned aspen/conifer

Figure 15-Difference plots obtained by subtracting daily mean, maximum, and minimum summertime soil temperatures under unburned aspen/conifer at Betenson and Grindstone Flats from their corresponding values under burned and cut aspen/conifer in Betenson and Grindstone Flat exclosures (solid lines) and from corresponding values under stable aspen at Betenson and Grindstone Flats (dotted line). 


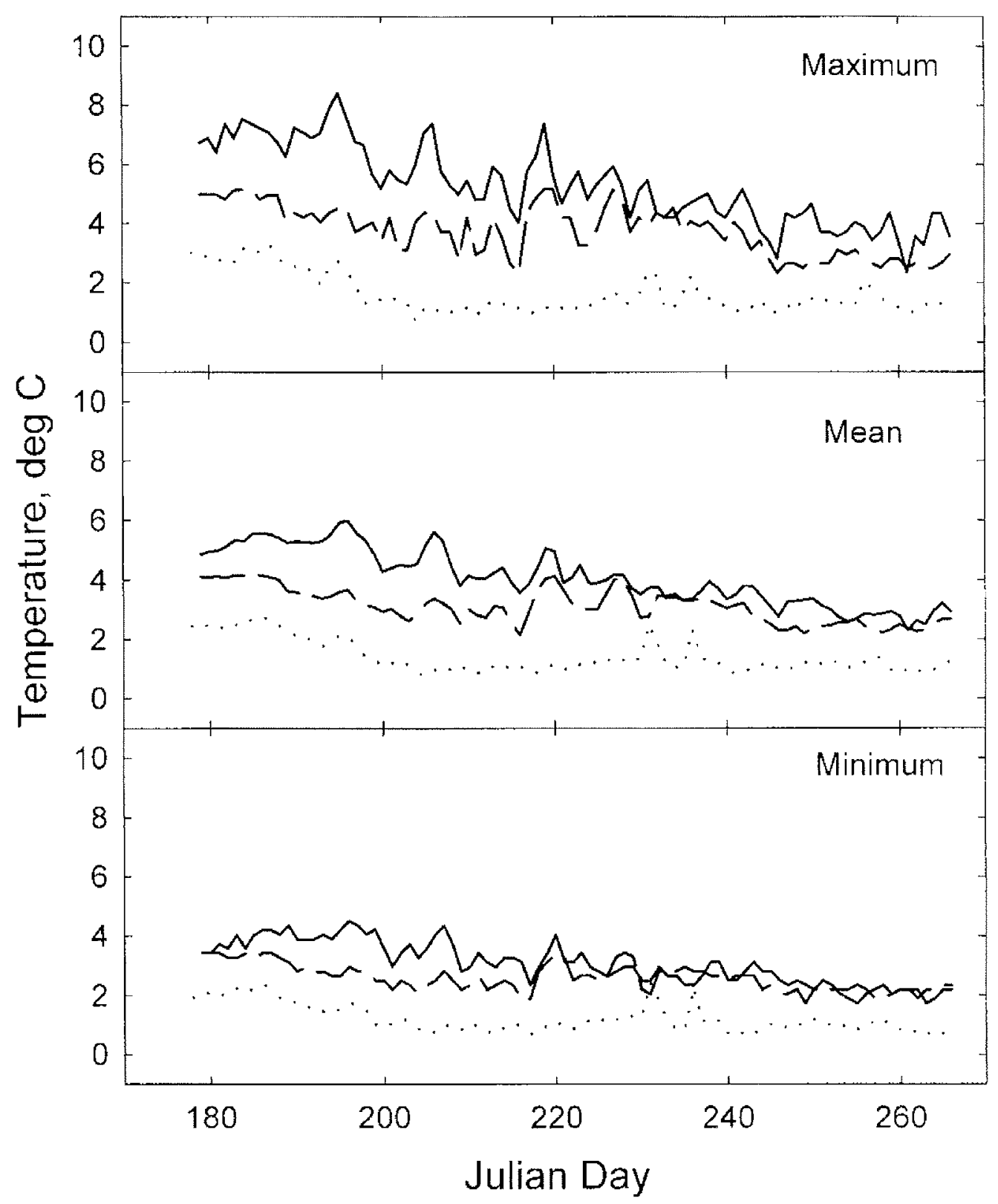

Solid line: Clearcut aspen/conifer - untreated aspen/conifer Dashed line: Decadent aspen - untreated aspen/conifer Dotted line: Stable aspen - untreated aspen/conifer

Figure 16-Difference plots obtained by subtracting daily mean, maximum, and minimum summertime soil temperatures under untreated aspen/conifer at White Ledge and Burnt Flat from their corresponding values under clearcut aspen/ conifer at White Ledge (solid line), decadent aspen on Burnt Flat (dashed line), and stable aspen on Burnt Flat (dotted line). 


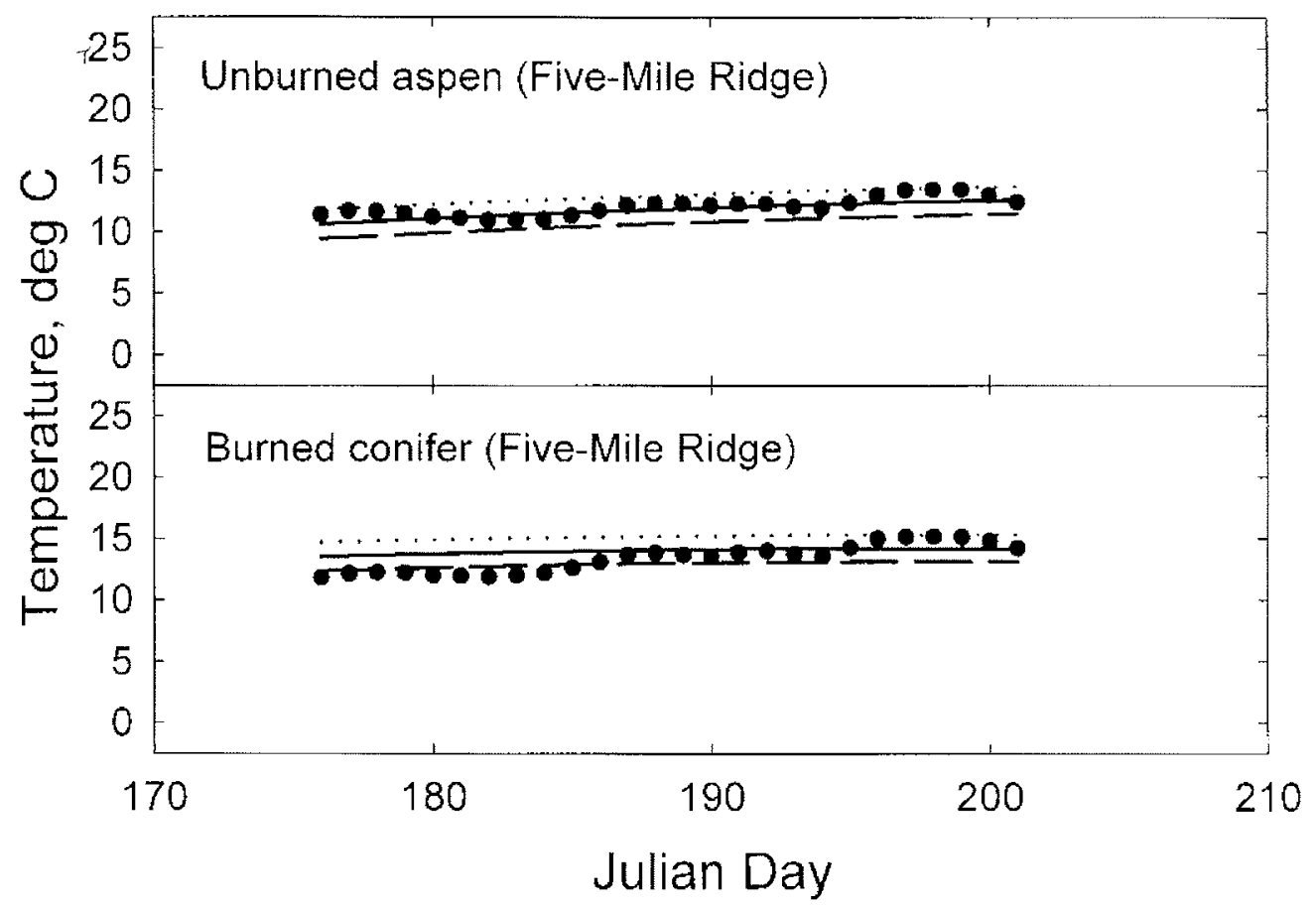

Figure 17-Daily mean summertime soil temperatures under unburned decadent aspen and burned conifer at Five-Mile Ridge, Dixie National Forest (filled circles) and fitted nonlinear regression lines with $95 \%$ confidence intervals (dotted lines).

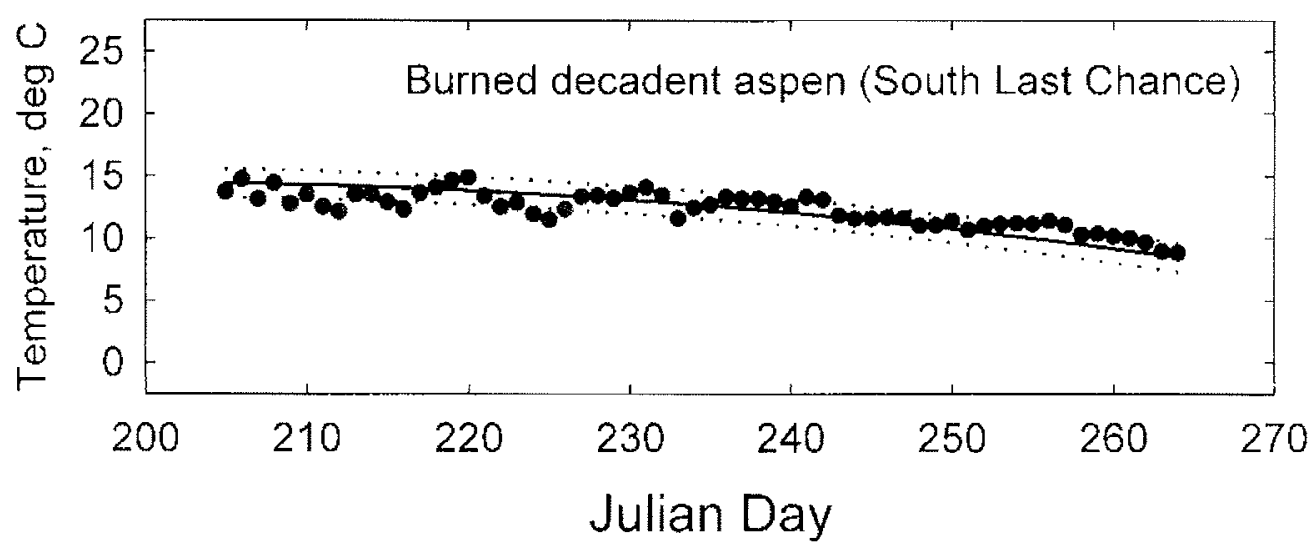

Figure 18-Daily mean summertime soil temperatures under burned decadent aspen in South Last Chance exclosure (filled circles) and fitted nonlinear regression line with $95 \%$ confidence intervals (dotted lines). 


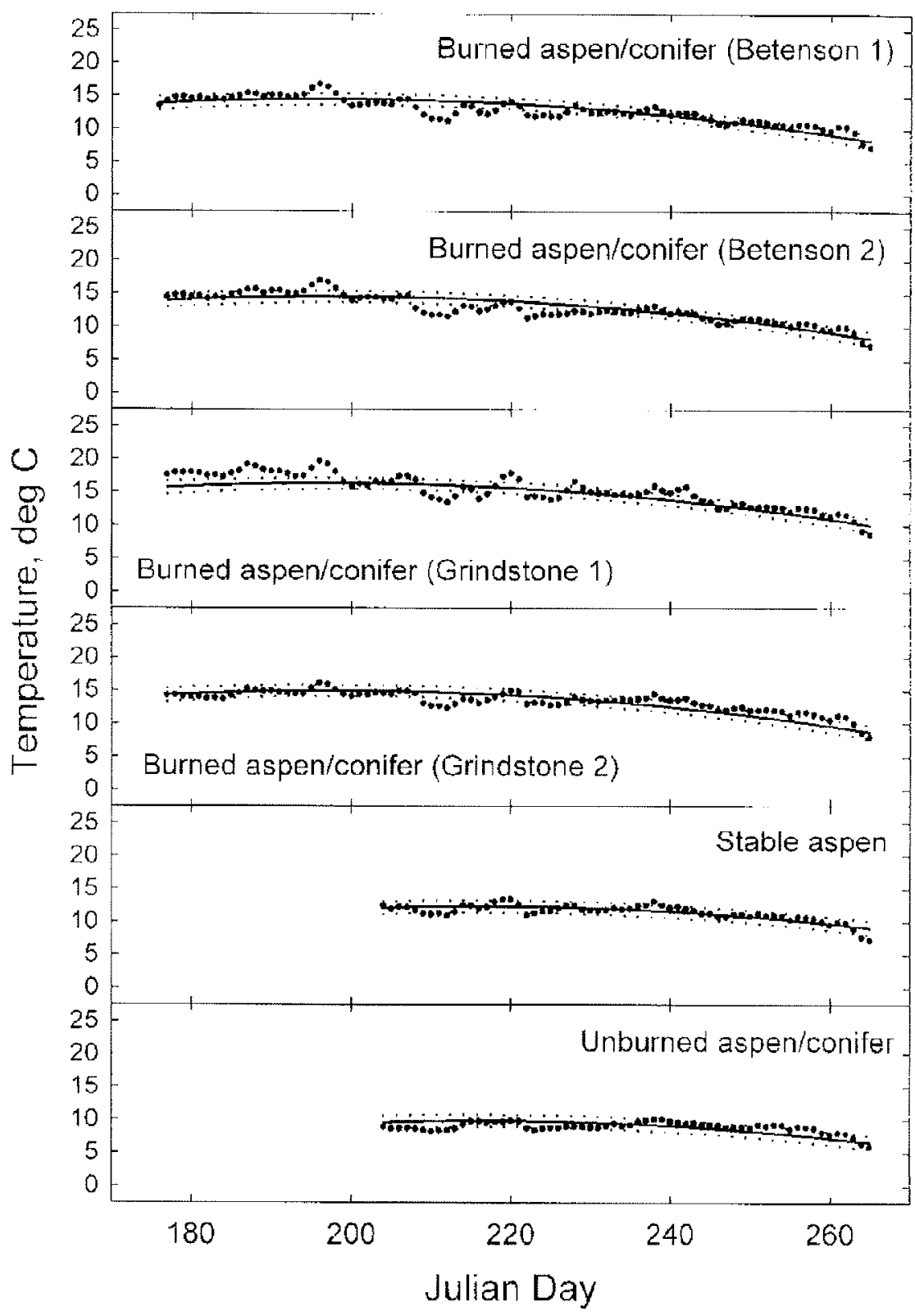

Figure 19-Daily mean summertime soil temperatures under burned and cut aspen/conifer in Betenson and Grindstone Flat exclosures and stable aspen and unburned aspen/conifer between Betenson and Grindstone Flats (filled circles) and fitted nonlinear regression lines with $95 \%$ confidence intervals (dotted lines). 


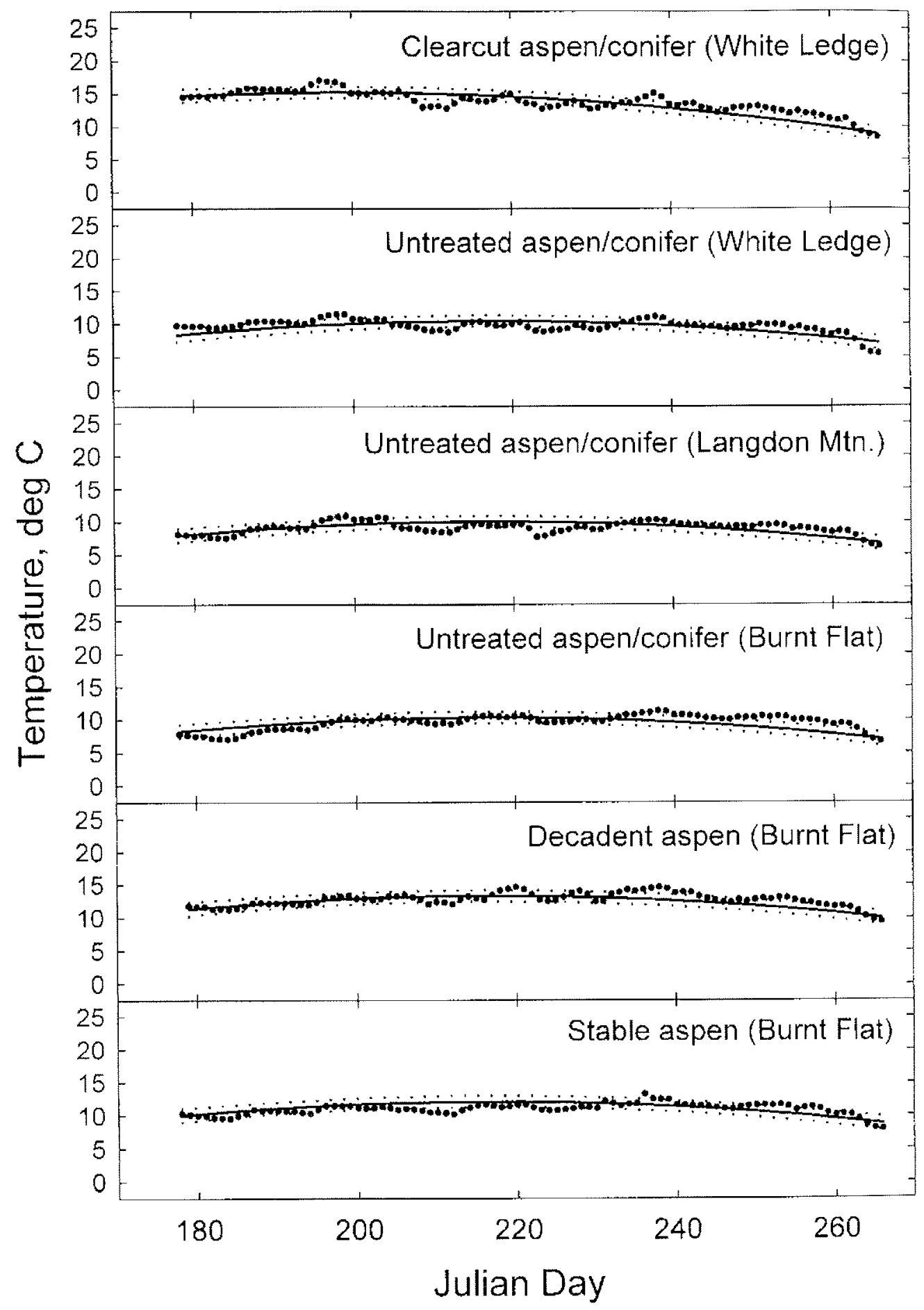

Figure 20-Daily mean summertime soil temperatures under clearcut aspen/ conifer at White Ledge, untreated aspen/conifer at White Ledge, Langdon Mountain, and Burnt Flat, and decadent and stable aspen on Burnt Flat (filled circles) and fitted nonlinear regression lines with $95 \%$ confidence intervals (dotted lines). 

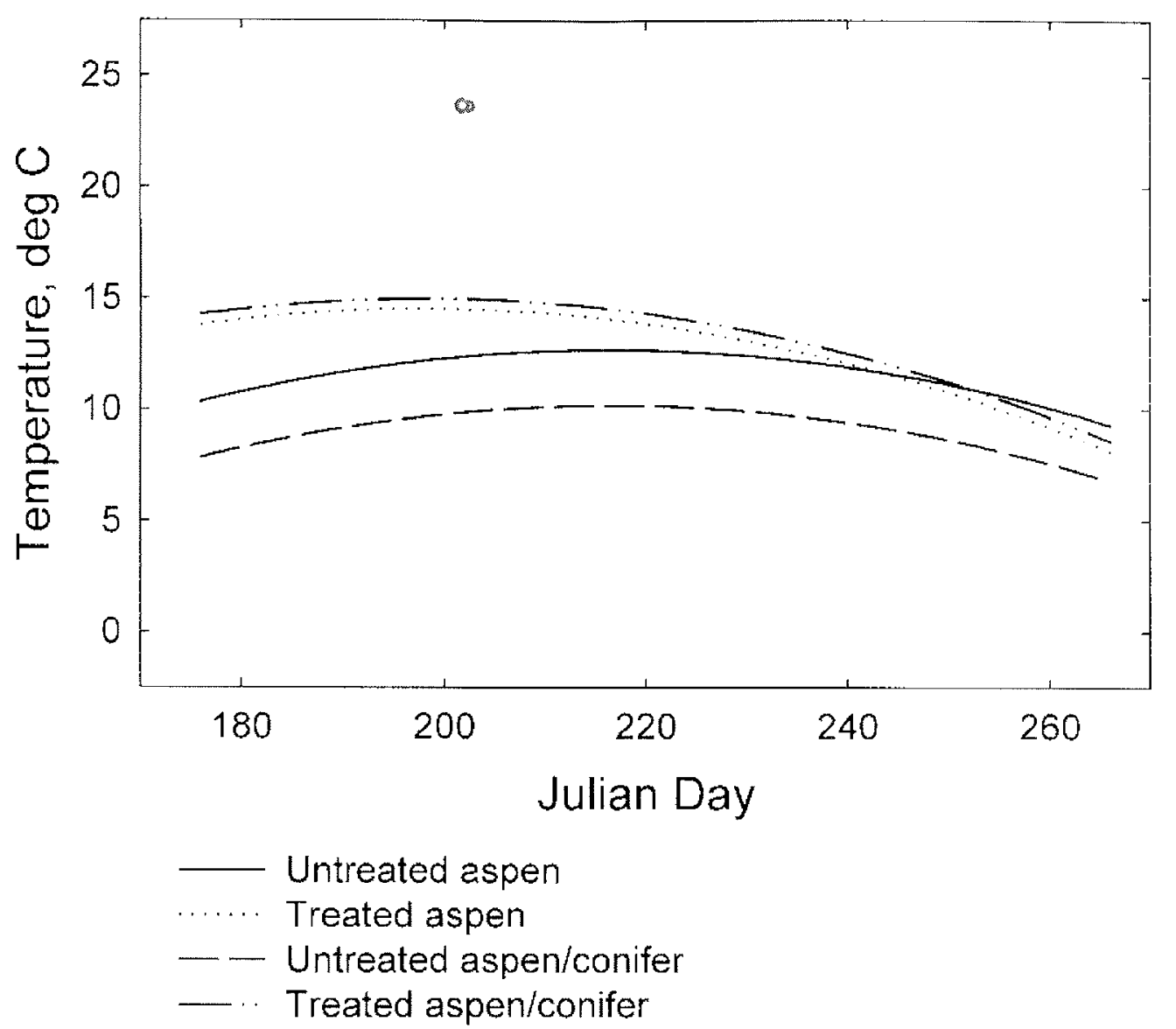

Figure 21-Predicted daily mean summertime soil temperatures $(10-\mathrm{cm}$ depth) under untreated aspen, treated (cut or burned) aspen, untreated aspen/ conifer, and treated (cut or burned) aspen/conifer.

Table 6-Quadratic regression coefficients for the relationships between daily mean summertime soil temperatures and Julian day for stand type (decadent or stable aspen, mixed aspen/conifer) and treatment (none, cut, or burned and cut). The quadratic regression equations are in the form of mean daily temperature $=a+b *$ Julian day $+c *(J u l i a n \text { day })^{2}$, where $a, b$, and $c$ are the regression coefficients.

\begin{tabular}{|c|c|c|c|c|c|}
\hline Location & Stand type & Treatment & a & $\mathbf{b}$ & $\mathrm{c}$ \\
\hline $\begin{array}{l}\text { Burnt Flat } \\
\text { Betenson/Grindstone Flats } \\
\text { Five-Mile Ridge }\end{array}$ & Decadent or stable aspen & None & -53.00 & 0.606 & -0.0014 \\
\hline South Last Chance & Decadent aspen & Burned and cut & -40.40 & 0.554 & -0.0014 \\
\hline $\begin{array}{l}\text { White Ledge - Langdon } \\
\text { Mountain - Burnt Flat } \\
\text { Betenson/Grindstone Flats }\end{array}$ & Mixed aspen/conifer & None & -55.51 & 0.606 & -0.0014 \\
\hline $\begin{array}{l}\text { White Ledge } \\
\text { Betenson/Grindstone Flats } \\
\text { Five-Mile Ridge }\end{array}$ & Mixed aspen/conifer & Cut or burned and cut & -39.95 & 0.554 & -0.0014 \\
\hline
\end{tabular}


remain cool throughout the summer (mean summertime soil temperatures of $<10 \mathrm{EC}$ ), show little diurnal variation in temperature (usually $<2 \mathrm{EC}$ ), do not reach maximum daily temperatures until late summer, and have little temperature trend throughout the summer (fig. 12, 13, 19, 20, A3, and A4).

In contrast, soils in the Pole Creek fire area on Betenson and Grindstone Flats had higher mean summertime soil temperatures because much of the tree canopy was eliminated by the fire and by the subsequent cutting (fig. 12 and 15). Also, the dark-colored ash layer absorbed heat. Because some of the insulating layer of conifer litter was destroyed in the Pole Creek fire, these soils showed more diurnal variation in temperature than unburned mixed aspen/conifer (fig. 12, 15, and A3).

Much of the conifer tree canopy and conifer litter layer survived the Five-Mile Ridge prescribed burn, which was less intense than the Pole Creek fire. Therefore, differences in soil temperature between unburned and burned areas were less at Five-Mile Ridge (fig. 14) than at Betenson and Grindstone Flats (fig. 15).

Soil temperature in burn areas at South Last Chance (prescribed burn), Betenson and Grindstone Flats (Pole Creek fire), and the White Ledge clearcut showed a marked decrease from mid to late summer that was not exhibited in untreated areas (fig. 18-20). We attribute this decrease in soil temperature after midsummer to an increase in shading caused by understory regrowth at the South Last Chance and White Ledge locations and developing aspen suckers at all locations. Also, the insulating effect of the litter layer in untreated mixed aspen/conifer stands delayed soil heating until later in the summer.

Soil temperature under stable aspen was lower than under decadent aspen because the leaf canopy was not as sparse, but was not as low as under mixed aspen/ conifer, which provides more shade (fig. 13, 16, and A4). However, we need additional soil temperature data under stable and decadent aspen stands to confirm this.

Summertime soil temperatures during the first summer after aspen restoration treatments (fire, clearcut, exclosures) and in stable aspen, decadent aspen, and mixed aspen/conifer stands followed the descriptive model presented in figure 1. A strong aspen suckering response was observed as a result of the aspen restoration treatments (Amacher and Bartos 1998), in part attributed to the warmer postfire and postharvest summertime soil temperatures. In time, we expect shading from the canopy of restored aspen stands to moderate the warmer postdisturbance summertime soil temperatures. Data from a prescribed burn in Idaho indicate that warmer summertime soil temperatures do not persist beyond the first year following treatment (Hungerford 1988). We will continue to monitor soil temperature in treated and untreated stands for at least 2 more years.

Although the effects of aspen to conifer succession and aspen restoration treatments on soil properties other than temperature are examined elsewhere (Amacher and Bartos 1998; Amacher and others 1999, in press; Bartos and Amacher 1998), some of the soil temperature effects will be discussed here. Amacher and others (1999, in press) found a large increase in soil nitrification in the Pole Creek fire burn area during the first, second, and third summers after the fire. The increase was attributed to the increase in soil $\mathrm{NH}_{4}$ after the fire, which is the substrate for soil microbial nitrification, a higher soil temperature in burned than unburned areas, and adequate soil moisture remaining in burn area soils even though soil water content was significantly less in burned than unburned areas. Soil nitrification rates in unburned mixed aspen/conifer stands were very low, probably because soil nitrification is very slow in cold wet soils (Stevenson 1986). Thus, warmer postfire soil temperatures affect aspen regeneration by stimulating suckering and by accelerating soil nitrification so that the increased $\mathrm{NO}_{3}$ production acts as a source of $\mathrm{N}$ for growth of aspen suckers until leaf fall and decay can again supply the nutritional needs of aspen (Amacher and others 1999, in press).

\section{References}

Amacher, M. C.; Bartos, D. L. 1998. Soil properties associated with aspen to conifer succession and aspen restoration treatments. In: Abstracts: $51^{\text {st }}$ annual meeting; Society for Range Management; 1998 Feb. 8-12; Guadalajara, Jalisco, Mexico. Denver, CO: Society for Range Management: 55.

Amacher, M. C.; Bartos, D. L., Christopherson, T.; Johnson, A. D.; Kutterer, D. E. [In press]. Nitrogen mineralization in aspen/ conifer soils after a natural fire. In: Sustaining aspen in western landscapes; 2000 June 13-15; Grand Junction, CO. Ft. Collins, CO:U.S. Department of Agriculture, Forest Service, Rocky Mountain Research Station.

Amacher, M. C.; Johnson, A. D.; Christopherson, T.; Kutterer, D. E.; Bartos, D. L.; Kotuby-Amacher, J. 1999. Nitrogen mineralization in the aspen ecosystem. In: Western nutrient management conference proceedings; 1999 March 4-5; Salt Lake City, UT. Twin Falls, ID: University of Idaho: 145-158.

Baker, F. S. 1925. Aspen in the central Rocky Mountain region. USDA Bull. 1291. Washington, DC: U.S. Department of Agriculture. $47 \mathrm{p}$.

Bartos, D. L.; Amacher, M. C. 1998. Soil properties associated with aspen to conifer succession. Rangelands 20(1): 25-28.

Bartos, D. L.; Brown, J. K.; Booth, G. D. 1994. Twelve years biomass response in aspen communities following fire. J. Range Manage. 47: 79-83.

Bartos, D. L.; Campbell, R. B., Jr. 1998a. Decline of quaking aspen in the interior west-examples from Utah. Rangelands 20(1): $17-24$.

Bartos, D. L.; Campbell, R. B. Jr. 1998b. Water depletion and other ecosystem values forfeited when conifer forests displace aspen communities. In: Potts, D. F., ed. Rangeland management and water resources; 1998 May 27-29; Reno, NV. Herndon, VA: American Water Resources Assoc.: 427-434. 
Bartos, D. L.; Debyle, N. V. 1981. Quantity, decomposition, and nutrient dynamics of aspen litterfall in Utah. Forest Sci. 27:381390.

Bartos D. L.; Mueggler, W. F. 1981. Early succession in aspen communities following fire in western Wyoming. J. Range Manage. $34: 315-318$.

Cryer, D. H.; Murray, J. E. 1992. Aspen regeneration and soils. Rangelands 14: 223-226.

Hallin, W. E. 1968. Soil surface temperatures on cutovers in southwest Oregon. Res. Note PNW-78. Portland, OR: U.S. Department of Agriculture, Forest Service, Pacific Northwest Forest and Range Experiment Station: $17 \mathrm{p}$.

Harniss, R. O. 1981. Ecological succession in aspen and its consequences. In: Debyle, N. V., ed. Situation management of two intermountain species: aspen and coyotes. Vol. 1. Aspen; 1981 April 23-24; Logan, UT. Logan, UT: Utah State Univ.: 31-39.

Hungerford, R. D. 1988. Soil temperatures and suckering in burned and unburned aspen stands in Idaho. Res. Note INT-378. Ogden, UT: U.S. Department of Agriculture, Forest Service, Intermountain Research Station: 6 p.

Hungerford, R. D.; Babbitt, R. E. 1987. Overstory removal and residue treatments affect soil surface, air and soil temperature: implications for seedling survival. Res. Pap. INT-377. Ogden, UT: U.S. Department of Agriculture, Forest Service, Intermountain Research Station: 20 p.

Jones, J. R.; Debyle, N. V. 1985a. Soils. In: Debyle, N. V.; Winokur R.P., eds. Aspen: ecology and management in the Western United States. Gen. Tech. Rep. RM-119. Ft. Collins, CO: U.S. Department of Agriculture, Forest Service, Rocky Mountain Forest and Range Experiment Station: 65-70.

Jones, J. R.; Debyle, N. V. 1985b. Fire. In: Debyle, N. V.; Winokur, R.P., eds. Aspen: ecology and management in the Western United States. Gen. Tech. Rep. RM-119. Ft. Collins, CO: U.S. Department of Agriculture, Forest Service, Rocky Mountain Forest and Range Experiment Station: 77-81.

Kay, C. E. 1985. Aspen reproduction in the Yellowstone Park Jackson Hole area and its relationship to the natural regulation of ungulates. In: Workman, G. W., ed. Western elk management: a symposium; 1984 April 19-20; Logan, UT. Logan, UT: Utah State Univ.: 131-160.

Kay, C. E. 1990. Yellowstone's northern elk herd: a critical evaluation of the "natural regulation" paradigm. Utah State Univ., Logan, UT. Dissertation, $490 \mathrm{p}$

Kay, C. E. 1993. Aspen seedlings in recently burned areas on Grand Teton and Yellowstone National Parks. Northwest Science 67: 94-104.

Kay, C. E. 1995. Aboriginal overkill and native burning: implications for modern ecosystem management. West. J. Appl. For. 10: $121-126$.
Kay, C. E. 1997. Is aspen doomed? J. For 95: 4-11.

Kay, C. E.; Patton B.; White, C. 1994. Assessment of long-term terrestrial ecosystem states and processes in Banff National Park and the central Canadian rockies. Banff, Alberta, Canada: Parks Canada, Banff National Park: $405 \mathrm{p}$

Littell, R. C.; Milliken, G. A.; Stroup, W. W.; Wolfinger, R. D. 1996. SAS system for mixed models. Cary, NC: SAS Institute Inc.: $633 \mathrm{p}$.

Maini, J.S.; Horton, K. W. 1966a. Reproductive response of Populus and associated Pteridium to cutting, burning and scarification. Dept. Publ. 1155. Ottawa, ON: Canadian Department of Forestry and Rural Development, Forestry Branch: $20 \mathrm{p}$.

Maini, J.S.; Horton, K. W. 1966b. Vegetative propagation of Populus spp. I. Influence of temperature on formation and initial growth of aspen suckers. Can. J. Bot. 44: 1183-1189.

Peterson, R. L. 1975. The initiation and development of root buds. In: Torrey, J. G.; Clarkson, D. T., eds. The development and function of roots. New York: Academic Press: 122-161.

Rust, R. H. 1983. Alfisols. In: Wilding, L. P.; Smeck, N. E.; Hall, G. F., eds. Pedogenesis and soil taxonomy. II. The soil orders. Amsterdam, The Netherlands: Elsevier Science Publishers B.V. 253-281.

Schier, G. A. 1981. Aspen regeneration. In: Debyle, N. V., ed. Situation management of two intermountain species: aspen and coyotes. Vol. 1. Aspen; 1981 April 23-24; Logan, UT. Logan, UT: Utah State Univ.: 15-21.

Schier, G. A.; Jones, J. R.; Winokur, R. P. 1985. Vegetative regeneration. In: DeByle, N. V.; Winokur, R. P., eds. Aspen: ecology and management in the Western United States. Gen. Tech. Rep. RM119. Ft. Collins, CO: U.S. Department of Agriculture, Forest Service, Rocky Mountain Forest and Range Experiment Station: 29-33.

Steneker, G. A., 1974. Factors affecting the suckering of trembling aspen. Forestry Chronicle 50:32-34.

Stevenson, F. J. 1986. Cycles of soil. New York: John Wiley \& Sons. $380 \mathrm{p}$.

White, C. A.; Olmstead, C. E.; Kay, C. E. 1998. Aspen, elk, and fire in the Rocky Mountain national parks of North America. Widl. Soc. Bull. 26:449-462.

Williams, K. R. 1972. The relationship of soil temperature and cytokinin production in aspen invasion. Albuquerque, NM: Univ. of New Mexico. Thesis. 39 p.

Winton, L. L. 1968. Plantlets from aspen tissue cultures. Science 160: $1234-1235$.

Wolter, K. E. 1968. Root and shoot initiation on aspen callus cultures. Nature 219:508-509.

Zasada, J.;Schier, G. A. 1973. Aspen root suckering in Alaska:effect of clone, collection date and temperature. Northwest Science 47 : $100-104$. 


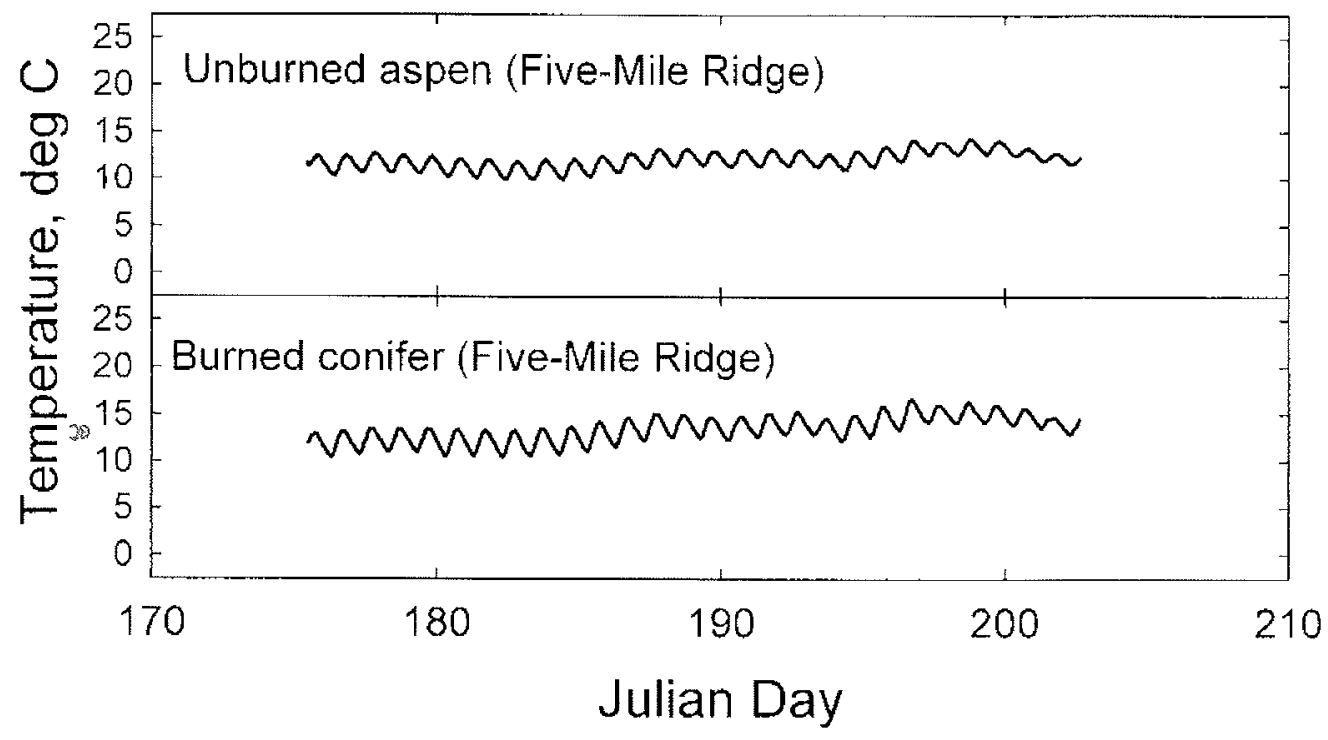

Figure A1-Hourly summertime (June 25, 1997, to July 20, 1997) soil temperatures (10-cm depth) under unburned decadent aspen and burned conifer at Five-Mile Ridge, Dixie National Forest.

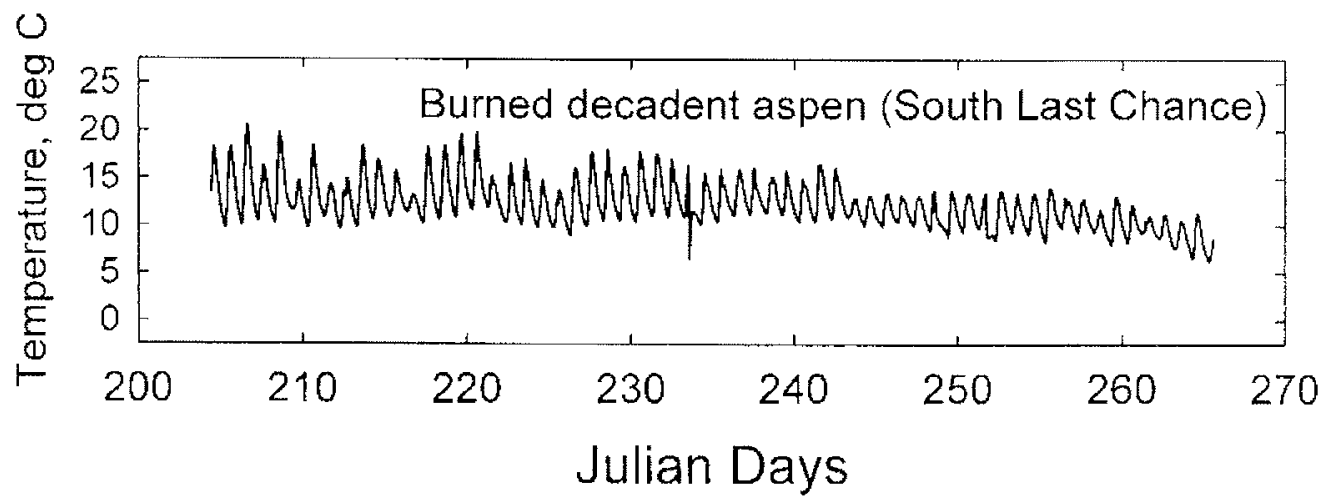

Figure A2-Hourly summertime (July 24, 1997, to September 21, 1997) soil temperatures $(10-\mathrm{cm}$ depth) under burned and cut decadent aspen in South Last Chance exclosure, Fishlake National Forest. 


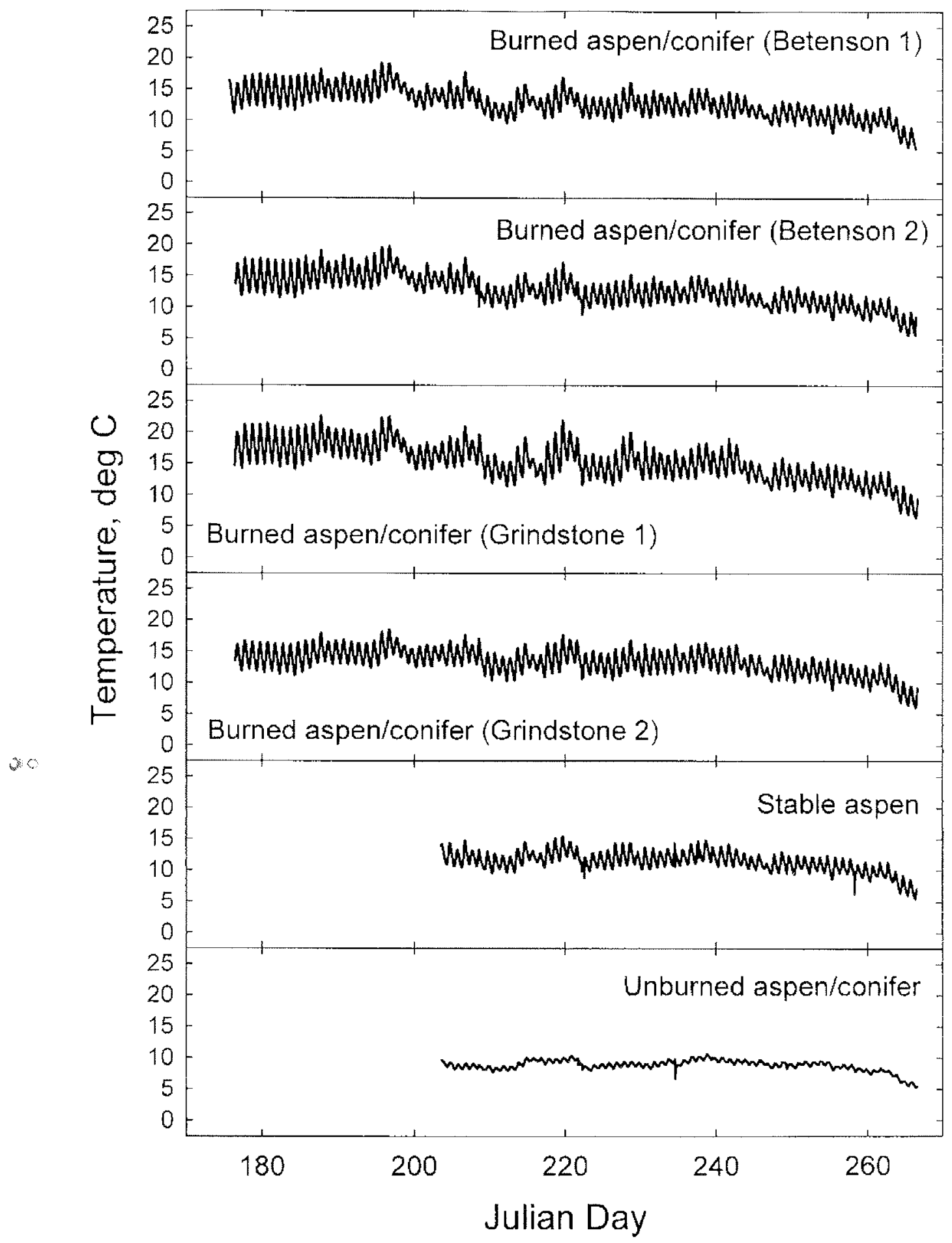

Figure A3-Hourly summertime (June 25, 1997, to September 22, 1997) soil temperatures (10-cm depth) under burned and cut aspen/conifer in Betenson and Grindstone Flat exclosures and stable aspen and unburned aspen/conifer between Betenson and Grindstone Flats, Fishlake National Forest. 


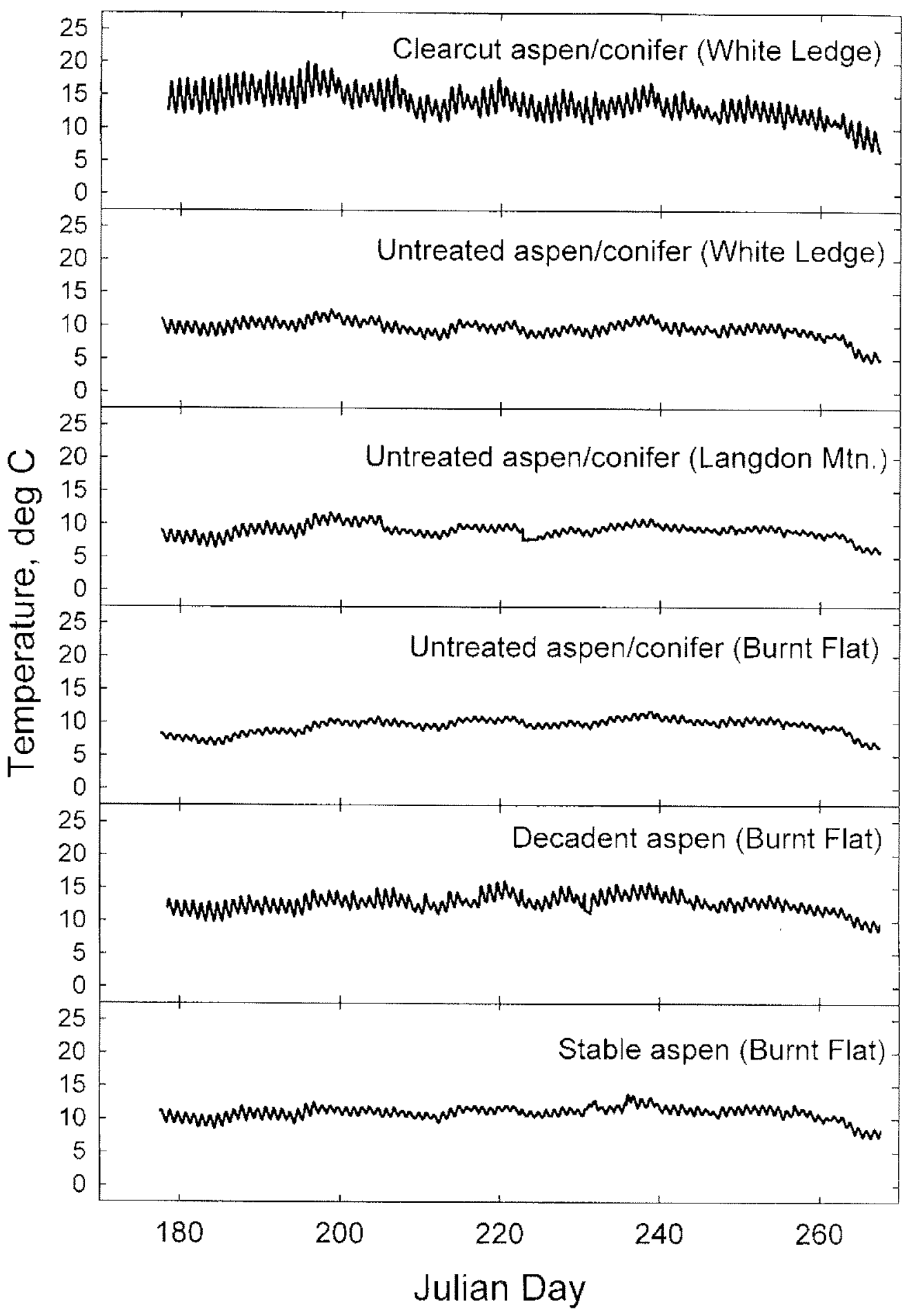

Figure A4-Hourly summertime (June 27, 1997, to September 23, 1997) soil temperatures (10-cm depth) under clearcut and untreated aspen/conifer at White Ledge; untreated aspen/conifer at Langdon Mountain; and untreated aspen/conifer, decadent aspen, and stable aspen at Burnt Flat, Fishlake National Forest. 


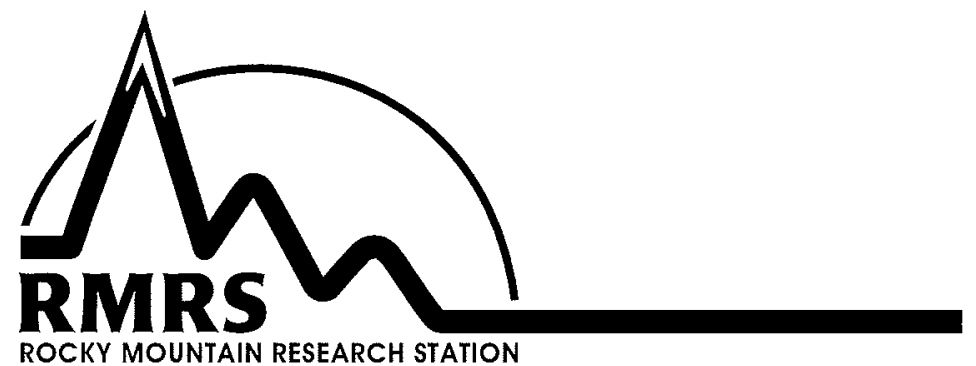

The Rocky Mountain Research Station develops scientific information and technology to improve management, protection, and use of the forests and rangelands. Research is designed to meet the needs of National Forest managers, Federal and State agencies, public and private organizations, academic institutions, industry, and individuals.

Studies accelerate solutions to problems involving ecosystems, range, forests, water, recreation, fire, resource inventory, land reclamation, community sustainability, forest engineering technology, multiple use economics, wildlife and fish habitat, and forest insects and diseases. Studies are conducted cooperatively, and applications may be found worldwide.

\section{Research Locations}

Flagstaff, Arizona

Fort Collins, Colorado*

Boise, Idaho

Moscow, Idaho

Bozeman, Montana

Missoula, Montana

Lincoln, Nebraska
Reno, Nevada

Albuquerque, New Mexico

Rapid City, South Dakota

Logan, Utah

Ogden, Utah

Provo, Utah

Laramie, Wyoming

*Station Headquarters, Natural Resources Research Center, 2150 Centre Avenue, Building A, Fort Collins, CO 80526

The U.S. Department of Agriculture (USDA) prohibits discrimination in all its programs and activities on the basis of race, color, national origin, sex, religion, age, disability, political beliefs, sexual orientation, or marital or family status. (Not all prohibited bases apply to all programs.) Persons with disabilities who require alternative means for communication of program information (Braille, large print, audiotape, etc.) should contact USDA's TARGET Center at (202) 720-2600 (voice and TDD).

To file a complaint of discrimination, write USDA, Director, Office of Civil Rights, Room 326-W, Whitten Building, 1400 Independence Avenue, SW, Washington, DC $20250-9410$ or call (202) $720-5964$ (voice or TDD). USDA is an equal opportunity provider and employer. 